\title{
Ultrafast Photochemistry of Copper(II) Monochlorocomplexes in Methanol and Acetonitrile by Broadband Deep-UV-to-Near-IR Femtosecond Transient Absorption Spectroscopy
}

\author{
Andrey S. Mereshchenko, ${ }^{* \dagger}{ }^{\dagger}$ Pavel K. Olshin, ${ }^{\dagger}$ Olesya S. Myasnikova, ${ }^{\dagger}$ Maxim S. Panov, ${ }^{\dagger}$ \\ Vladimir A. Kochemirovsky, ${ }^{\dagger}$ Mikhail Yu. Skripkin, ${ }^{\dagger}$ Pavel N. Moroz, ${ }^{\ddagger}$, Mikhail Zamkov, ${ }^{\ddagger}, \|$ \\ and Alexander N. Tarnovsky*,\$, \\ ${ }^{\dagger}$ Saint-Petersburg State University, 7/9 Universitetskaya nab., St. Petersburg, 199034 Russia \\ ${ }^{\ddagger}$ Center for Photochemical Sciences, ${ }^{\S}$ Department of Chemistry, and "Department of Physics, Bowling Green State University, \\ Bowling Green, Ohio 43403, United States
}

Supporting Information

ABSTRACT: Photochemistry of copper(II) monochlorocomplexes in methanol and acetonitrile solutions is studied by UV-pump/broadband deep-UV-to-near-IR probe femtosecond transient absorption spectroscopy. Upon 255 and $266 \mathrm{~nm}$ excitation, the complexes in acetonitrile and methanol, respectively, are promoted to the excited ligand-to-metal charge transfer (LMCT) state, which has a short (sub-250 fs) lifetime. From the LMCT state, the complexes decay via internal conversion to lower-lying ligand field $(\mathrm{LF}) \mathrm{d}-\mathrm{d}$ excited states or the vibrationally hot ground electronic state. A minor fraction of the excited complexes relaxes to the LF electronic excited states, which are relatively long-lived with lifetimes $>1 \mathrm{~ns}$. Also, in methanol solutions, about $3 \%$ of the LMCT-excited copper(II) monochlorocomplexes dissociate forming copper(I) solvatocomplexes and chlorine atoms, which then further react forming long-lived photoproducts. In acetonitrile, about $50 \%$ of the LMCT-excited copper(II) monochlorocomplexes dissociate forming radical and ionic products in a ratio of 3:2. Another minor process observed following excitation only in methanol solutions is the re-equilibration between several forms of the copper(II) ground-state complexes present in solutions. This re-equilibration occurs on a time scale from sub-nanoseconds to nanoseconds.

\section{INTRODUCTION}

Copper complexes have been the subject of extensive studies for a long time. A wide range of the interrelated topics to which copper complexes are central, such as copper metal protein structures and properties, chemical reaction dynamics, catalysis, and photobiology was investigated. Photo- and thermochemistry of soluble copper complexes is also of importance to applied chemistry, especially in laser-induced deposition of metal copper from solution. It is possible to control electrochemical, catalytic and sensor properties of such metal micro- and nanostructured materials by varying the laser parameters and the solution composition. For these studies, nonaqueous solutions are of particular interest because up to now most of the laser-induced metal deposition experiments were performed in aqueous media. ${ }^{1}$ Copper(II) complexes are labile, and therefore, they have been used as model systems to study the dynamics of the ligand exchange mechanism. ${ }^{2-5}$ Also, copper plays a significant role in the metabolism of the human's body. Copper enzymes perform important functions, such as the catalysis of biological reactions (for example, conversion of dopamine to noradrenaline $e^{6,7}$ ), electron transfer, and protection of cells against free radicals. ${ }^{8}$ Copper metabolic disorder leads to arthritis, ${ }^{9}$ mental disorders, ${ }^{10}$ and loss of fertility ${ }^{11}$ and

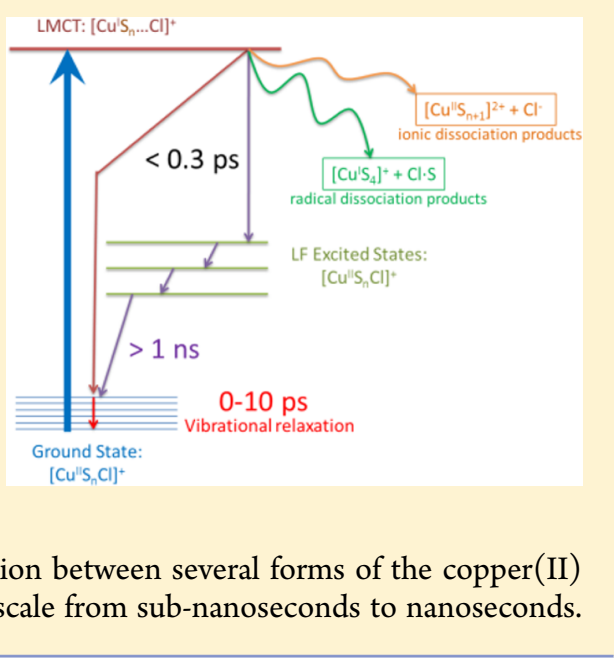

even to life-threatening diseases such as Menkes' syndrome $^{12-14}$ and Wilson's disease. ${ }^{8,15,16}$ In photobiology, copper based proteins, such as plastocyanin and umecyanin, are responsible for electron transfer in photosynthesis processes. $^{17-19}$ In plants and cyanobacteria, light energy is captured to be stored in the form of sugars by two proteins called photosystem I and photosystem II. Plastocyanin is a copper(II)-based protein, which transfer electrons from photosystem II to photosystem I. In the literature, ligand-tometal charge transfer (LMCT) photoexcitation of copper blue proteins is regarded as an analogue of the actual biological electron transfer. ${ }^{20}$

Dynamics of copper(II) complexes following LMCT excitation was most actively studied for blue copper proteins, such as the plastocyanin, human ceruloplasmin, umecyanin, rusticyanin, azurin, etc., ${ }^{20-29}$ where it occurs on an ultrafast time scale. However, there is no unique interpretation of the photophysical mechanism. For example, some authors have demonstrated that LMCT excitation of blue copper proteins

Received: December 22, 2015

Revised: February 22, 2016

Published: February 22, 2016 
resulted in direct internal conversion into the ground electronic state in less than $300 \mathrm{fs}^{21,22,27-29}$ Meanwhile, others authors have shown that excitation of blue copper proteins into the LMCT state led to a stepwise relaxation into the ground state via lower-lying $\mathrm{LF}$ states. ${ }^{20,23,24} A b$ initio calculations of plastocyanin at ORMAS/MCSCF and CASSCF/MCQDPT levels of theory show that the LMCT states are repulsive along the $\mathrm{Cu}-\mathrm{S}(\mathrm{Cys})$ reaction coordinate, and the LMCT states cross the ligand field (LF) excited states and the ground state at the $\mathrm{Cu}-\mathrm{S}(\mathrm{Cys})$ distances longer than $2.7 \AA$, and the $\mathrm{Cu}-$ $\mathrm{N}$ (His) distance of about $2.1 \AA^{25}$ The molecular dynamics study of plastocyanin predicts that the LMCT states relax to the LF states through either ballistic and coherent potential energy surface crossing within $70-80$ and $500 \mathrm{fs}$, respectively. ${ }^{26}$

In a large number of studies, in which time-resolved spectroscopy $^{30,31}$ and steady-state photochemical methods, such as spectrophotometrical analysis ${ }^{32-36}$ and separation of photoreaction products followed by their identification ${ }^{37-39}$ were used, it has been shown that the LMCT excited states of copper(II) complexes are dissociative, usually resulting in the photoreduction of copper(II) to copper(I). In these studies, the authors reported low quantum yields of the copper(I) formation rarely exceeding $10 \%$, indicating that the LMCT states predominately relax into the electronic ground state rather than dissociate. In addition, the LF and LMCT excited states are known to form exciplexes with the Lewis bases such as THF, DMF, DMSO, acetonitrile, pyridine, etc. ${ }^{40-42}$

Photochemistry of the copper(II) halide complexes has been studied mostly by analyzing the reaction mixture after continuous irradiation. ${ }^{34-39}$ Briefly, LMCT excitation of the halide complexes results in photoreduction of copper(II) to copper(I) and halogen atom formation with a quantum yield of several percent. Halogen atoms then can react with other components of the reaction mixture, for example, with the solvent molecules. ${ }^{34,37}$ In our previous work by means of femtosecond pump-probe spectroscopy, we showed that upon LMCT excitation of the copper(II) monochlorocomplex in methanol, the major relaxation pathway is internal conversion into the vibrationally hot ground electronic state. ${ }^{31}$ However, a minor portion of the excited molecules undergoes photodissociation with the formation of copper(I) solvatocomplexes and chlorine atoms. The lifetime of the monitored LMCT excited state was shorter than the temporal width of the instrument response function $(\approx 200 \mathrm{fs}$, fwhm $)$.

In this work, we have studied copper(II) monochlorocomplexes following LMCT excitation in methanol and acetonitrile solutions by means of femtosecond transient absorption spectroscopy with broadband deep-UV-to-near-IR probing $(212-760 \mathrm{~nm})$. In addition to previously reported nonradiative relaxation pathways, namely, internal conversion into the vibrational hot ground electronic state and breaking of a $\mathrm{Cu}-$ $\mathrm{Cl}$ bond with the elimination of the chlorine atom, the longlived (lifetime $>1 \mathrm{~ns}$ ) LF excited state for copper(II) monochlorocomplexes in both solvents and $\mathrm{Cu}-\mathrm{Cl}$ bond breaking with the elimination of the chloride ion for copper(II) monochlorocomplex in acetonitrile are observed.

\section{MATERIALS AND METHODS}

Time-resolved transient absorption $(\Delta A)$ spectra were measured using the experimental setup based on a regeneratively amplified Ti:sapphire laser system (Hurricane, SpectraPhysics, $800 \mathrm{~nm}, 1 \mathrm{kHz}$ ) that has been described previously. ${ }^{31,43-49}$ An optical parametric amplifier (TOPAS-C,
Light Conversion Ltd.) was used to generate 255 or $266 \mathrm{~nm}$ excitation ("pump") pulses. "Probe" pulses were produced either by using another TOPAS-C in the range from 210 to 384 $\mathrm{nm}$ or by using white-light continuum in the $340-760 \mathrm{~nm}$ range generated by focusing a small portion of the amplified $800 \mathrm{~nm}$ light into a $3 \mathrm{~mm} \mathrm{CaF}_{2}$ window. The probe beam was focused onto the sample to a $160-\mu \mathrm{m}$ diameter spot and overlapped at an angle of $6^{\circ}$ with the pump beam focused to a $460-\mu \mathrm{m}$ diameter spot. To eliminate the contributions of solute rotational motion to $\Delta A$ signals, the polarization of the pump beam was set at the magic angle $\left(54.7^{\circ}\right)$ with respect to that of the probe beam. The pump pulse energy was $6 \mu \mathrm{J}$. The linearity of copper(II) chlorocomplexes-related $\Delta A$ signals with excitation energy was ensured. The measured solutions were circulated through a $0.2 \mathrm{~mm}$ Spectrosil UV quartz flow cell.

All $\Delta A$ signals were corrected for the group velocity dispersion (GVD) of the probe light with the $25 \mathrm{fs}$ accuracy, utilizing the peak position of the instrument response function (IRF) signals, namely Gaussian-shaped $\Delta A$ signals observed in neat solvents as a result of the simultaneous absorption of a pump and a probe photon when the pump and probe pulses temporally overlap. $^{47,50-52}$ The description of the $\Delta A$ time evolution of the selected kinetics traces was obtained by fitting the data to a sum of exponential functions: $\Delta A(t)_{\lambda=\text { const }}=A_{0}+$ $\sum_{i=1}^{N} A_{i} \mathrm{e}^{-t / \tau_{i}}$, where $\lambda$ is the probe wavelength, $t$ is the delay time, $N=2-4$ is the number of exponential functions, $A_{0}$ is the permanent signal amplitude that that does not decay within the investigated time scale of $1 \mathrm{~ns}, \tau_{i}$ is the time constant, and $A_{i}$ is the signal amplitude of the $i$ exponential component. For a specific fit, the number of exponential components was chosen such that further increase of the number of the exponential components does not improve the goodness of the fit judged by its $\chi^{2}$ value.

Copper(II) perchlorate hexahydrate (98\%), tetraethylammonium perchlorate $(>98 \%)$, tetraethylammonium chloride (>98\%), lithium chloride (>99\%), copper powder (>99\%), murexide, ethylenediaminetetraacetic acid disodium salt aqueous solution $(0.1 \mathrm{M})$, ammonium chloride $(\geq 99.5 \%)$, ammonium hydroxide aqueous solution (28.0-30.0\%), methanol (>99.8\%), and acetonitrile (>99.5\%) were purchased from Sigma-Aldrich. Tetraethylammonium chloride ( $>98 \%)$, tetraethylammonium perchlorate $(>98 \%)$, and lithium chloride (>99\%) were dried in vacuum oven at $110{ }^{\circ} \mathrm{C}$ for $10 \mathrm{~h}$. Chloroacetone (95\%) was purchased from Alfa Aesar, and used without additional purification. Tetrakis(acetonitrile)copper(I) perchlorate was prepared by the reduction of copper(II) perchlorate by copper powder in acetonitrile, followed by drying under argon. ${ }^{31,53}$ To prepare copper(II)-containing solutions, stock solutions of copper(II) perchlorate $\left(\left[\mathrm{Cu}^{2+}\right]=\right.$ $0.2 \mathrm{M}$ ) were prepared by dissolving copper(II) perchlorate hexahydrate in acetonitrile and methanol, which was followed by complexometric titration. Ethylenediaminetetraacetic acid disodium salt solution $(0.1 \mathrm{M})$, and murexide were used as titrant and indicator, respectively. The titration was performed in ammonium chloride-ammonium hydroxide buffer solution, containing $0.1 \mathrm{M}$ ammonium chloride and $0.1 \mathrm{M}$ ammonium hydroxide.

The UV-vis-NIR-IR absorption spectra were measured using Varian Cary 50 UV-vis and Perkin Elmer Lambda 750 UV-vis-IR spectrophotometers. The UV absorption spectra measured before and after time-resolved measurements have shown the sample decomposition less than a few percent. All experiments were performed at $21^{\circ} \mathrm{C}$. 


\section{RESULTS}

3.1. Steady-State Absorption. In methanol and acetonitrile solutions, copper(II) ions form $\left[\mathrm{Cu}^{\mathrm{II}}(\mathrm{MeOH})_{6}\right]^{2+33,54}$ and $\left[\mathrm{Cu}^{\mathrm{II}}(\mathrm{MeCN})_{4}\right]^{2+55,56}$ solvatocomplexes, respectively. Upon addition of chloride ions, the formation of highly labile chlorocomplexes $\left[\mathrm{Cu}^{\mathrm{II}}(\mathrm{MeOH})_{6-n} \mathrm{Cl}_{n}\right]^{2-n}$ and $\left[\mathrm{Cu}^{\mathrm{II}}(\mathrm{MeCN})_{4-n} \mathrm{Cl}_{n}\right]^{2-n}(n=1-4)$ takes place, for methanol and acetonitrile solutions, respectively. These copper(II) chlorocomplexes have the characteristic electronic absorption spectra with the spectral shape depending on the number of the chloride ligands ${ }^{57-59}$ and the nature of the solvent. For methanol and acetonitrile solutions, the absorption spectra of the individual complexes and their overall stability constants are known, ${ }^{57,60}$ Figure 1. The equilibrium concentrations of the
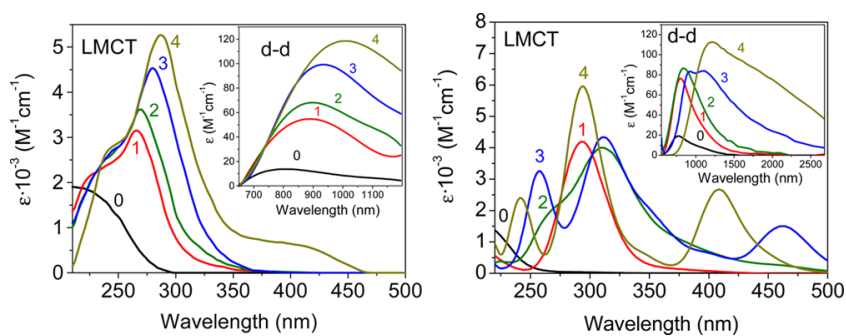

Figure 1. Steady-state absorption spectra of individual chloro complexes of copper(II) in methanol (left panel, adopted from the literature, ${ }^{31,57}$ overall stability constants: $\beta_{1}=2.8 \times 10^{2}, \beta_{2}=1.6 \times 10^{4}$, $\beta_{3}=2.3 \times 10^{5}$, and $\left.\beta_{4}=4.5 \times 10^{5}\right)$, $\left[\mathrm{Cu}^{\mathrm{II}}(\mathrm{MeOH})_{6-n} \mathrm{Cl}_{n}\right]^{2-n}$, and in acetonitrile (right panel, reported previously, ${ }^{60}$ overall stability constants: $\beta_{1}=3.4 \times 10^{8}, \beta_{2}=4.3 \times 10^{15}, \beta_{3}=2.8 \times 10^{22}$, and $\beta_{4}$ $\left.=5.1 \times 10^{25}\right),\left[\mathrm{Cu}^{\mathrm{II}}(\mathrm{MeCN})_{4-n} \mathrm{Cl}_{n}\right]^{2-n}$, where $n=0-4$.

copper(II) chlorocomplexes are determined by the initial concentrations of copper(II) and chloride ions. Fractional distribution of the copper(II) chlorocomplexes depending on initial concentration of chloride ions at the constant initial concentration of copper(II) ions $(50 \mathrm{mM})$ in methanol and acetonitrile was estimated using the "Medusa" software, developed by Ignasi Puigdomenech, Royal Institute of Technology (KTH), Sweden, ${ }^{61}$ Figure 2. To maximize the relative concentration of the copper(II) monochlorocomplex, following solutions were utilized in the experiments: $50 \mathrm{mM}$
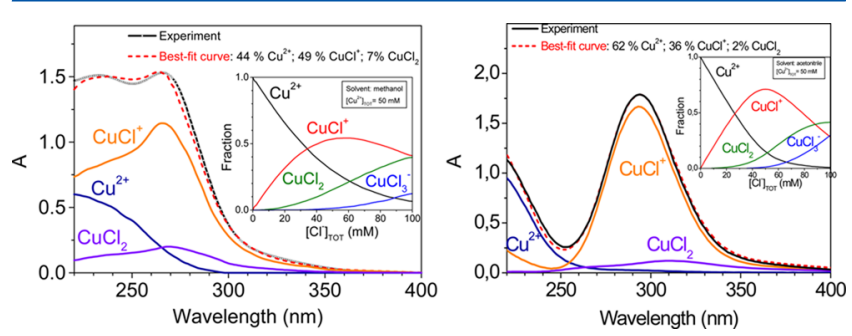

Figure 2. Steady-state absorption spectrum of a methanol solution containing $\mathrm{Cu}\left(\mathrm{ClO}_{4}\right)_{2}(50 \mathrm{mM})$ and $\mathrm{LiCl}(25 \mathrm{mM})$ (left panel) and an acetonitrile solution containing $\mathrm{Cu}\left(\mathrm{ClO}_{4}\right)_{2}(50 \mathrm{mM})$ and $\mathrm{NEt}_{4} \mathrm{Cl}$ $(25 \mathrm{mM})$ (right panel ${ }^{31}$ ) measured in a $0.2 \mathrm{~mm}$ cell (line and symbols). The best-fit spectra obtained using the known $\varepsilon$ values of the individual copper(II) complexes as the parameters and their fractional concentrations as the variables are shown by a dashed line. The distribution of chlorocomplexes of copper(II) as a function of concentration of chloride ions was also calculated by Medusa software (inset).
$\mathrm{Cu}\left(\mathrm{ClO}_{4}\right)_{2}-25 \mathrm{mM} \mathrm{LiCl}$ in methanol and $50 \mathrm{mM} \mathrm{Cu}\left(\mathrm{ClO}_{4}\right)_{2}$ $-25 \mathrm{mM} \mathrm{NEt}_{4} \mathrm{Cl}$ in acetonitrile.

Under these conditions, using the known stability constants, we calculated with the help of "Medusa" software that more than $93 \%$ of copper(II) exist as a mixture of the pure solvatocomplexes and monochlorocomplexes, with a small contribution from the dichlorocomplexes (Figure 2). Specifically, the mixture consists of $44 \%$ of $\left[\mathrm{Cu}^{\mathrm{II}}(\mathrm{MeOH})_{6}\right]^{2+}, 49 \%$ of $\left[\mathrm{Cu}^{\mathrm{II}}(\mathrm{MeOH})_{5} \mathrm{Cl}\right]^{+}$, and $7 \%$ of $\left[\mathrm{Cu}^{\mathrm{II}}(\mathrm{MeOH})_{4} \mathrm{Cl}_{2}\right]$ in methanol. ${ }^{31}$ In acetonitrile, the mixture consists of $62 \%$ of $\left[\mathrm{Cu}^{\mathrm{II}}(\mathrm{MeCN})_{4}\right]^{2+}, 36 \%$ of $\left[\mathrm{Cu}^{\mathrm{II}}(\mathrm{MeCN})_{3} \mathrm{Cl}\right]^{+}$, and $2 \%$ of $\left[\mathrm{Cu}^{\mathrm{II}}(\mathrm{MeCN})_{2} \mathrm{Cl}_{2}\right]$. Moreover, the measured steady-state spectra of the $50 \mathrm{mMCu}\left(\mathrm{ClO}_{4}\right)_{2}-25 \mathrm{mM} \mathrm{LiCl}$ solution in methanol and $50 \mathrm{mM} \mathrm{Cu}\left(\mathrm{ClO}_{4}\right)_{2}-25 \mathrm{mM} \mathrm{NEt}_{4} \mathrm{Cl}$ solution in acetonitrile can be fitted to a sum of the absorption spectra of the pure copper(II) solvatocomplexes, monochlorocomplexes, and dichlorocomplexes (Figure 2). In these fits, the known molecular extinction coefficients were held constant and the concentrations of these complexes were varied. The best fit results in the following fractional distribution: $44 \%$ of $\left[\mathrm{Cu}^{\mathrm{II}}(\mathrm{MeOH})_{6}\right]^{2+}, 49 \%$ of $\left[\mathrm{Cu}^{\mathrm{II}}(\mathrm{MeOH})_{5} \mathrm{Cl}\right]^{+}$, and $7 \%$ of $\left[\mathrm{Cu}^{\mathrm{II}}(\mathrm{MeOH})_{4} \mathrm{Cl}_{2}\right]$ in methanol, ${ }^{31}$ and $51 \%$ of $\left[\mathrm{Cu}(\mathrm{MeCN})_{4}\right]^{2+}, 47 \%$ of $\left[\mathrm{Cu}^{\mathrm{II}}(\mathrm{MeCN})_{3} \mathrm{Cl}\right]^{+}$, and $2 \%$ of $\left[\mathrm{Cu}^{\mathrm{II}}(\mathrm{MeCN})_{2} \mathrm{Cl}_{2}\right]$ in acetonitrile. Thus, the fractional distributions obtained from the fit of the steady-state absorption spectra and those calculated by "Medusa" software agree reasonably well. The small difference in the values probably arises from the experimental accuracy in determining $\mathrm{Cu}\left(\mathrm{ClO}_{4}\right)_{2}$ and $\mathrm{NEt}_{4} \mathrm{Cl}$ concentrations $( \pm 5 \%)$, and from not taking into account the ionic strengths of solutions in "Medusa" calculations. Using the results of the absorption fits the excitation wavelength was set to 255 and $266 \mathrm{~nm}$ in transient absorption experiments to preferentially excite the $\left[\mathrm{Cu}^{\mathrm{II}}(\mathrm{MeOH})_{5} \mathrm{Cl}\right]^{+}$complex in methanol and the $\left[\mathrm{Cu}^{\mathrm{II}}(\mathrm{MeCN})_{3} \mathrm{Cl}\right]^{+}$complex in acetonitrile, respectively.

To characterize the UV-vis spectrum of a thermally stable copper(I) solvatocomplex in acetonitrile, tetrakis (acetonitrile) copper(I) perchlorate $(3 \mathrm{mM})$ was dissolved in deoxygenated acetonitrile. The absorption spectrum of the copper(I) solvatocomplex in methanol was adopted from the previous work. ${ }^{31}$ Copper(I) solvatocomplexes are expected to adopt the tetrahedral structure in these solvents: ${ }^{31,55}$ namely, $\left[\mathrm{Cu}^{\mathrm{I}}(\mathrm{MeOH})_{4}\right]^{+}$and $\left[\mathrm{Cu}^{\mathrm{I}}(\mathrm{MeCN})_{4}\right]^{+}$. The electronic absorption spectrum of $\left[\mathrm{Cu}^{\mathrm{I}}(\mathrm{MeOH})_{4}\right]^{+}$consists of an intense band with the maximum at $211 \mathrm{~nm}\left(\varepsilon=6800 \mathrm{M}^{-1} \mathrm{~cm}^{-1}\right)$ and two shoulders at about 240 and $290 \mathrm{~nm}{ }^{31}$ whereas that of $\left[\mathrm{Cu}^{\mathrm{I}}(\mathrm{MeCN})_{4}\right]^{+}$consists of a highly intense band with the maximum at $209 \mathrm{~nm}\left(\varepsilon=19800 \mathrm{M}^{-1} \mathrm{~cm}^{-1}\right)$ with a shoulder at $230 \mathrm{~nm}$ (Figure 5S, 7).

3.2. Ultrafast Transient Absorption Measurements. 3.2.1. Methanol. Previously, the photochemistry of the copper(II) monochlorocomplex in methanol was studied by means of ultrafast transient absorption with probing in the UV range. $^{31}$ In this work, we investigated a significantly broader probing range from 212 to $760 \mathrm{~nm}$ (Figure 3). The wide range of probe wavelengths is a superb advantage for the detection of the intermediates at different stages of the reaction, during which they absorb photons with significantly different energies.

Ultrafast time-resolved transient absorption $\Delta A$ spectra and corresponding kinetic traces following $255 \mathrm{~nm}$ excitation of 50 $\mathrm{mM} \mathrm{Cu}\left(\mathrm{ClO}_{4}\right)_{2}-25 \mathrm{mM} \mathrm{LiCl}$ methanol solution are shown in Figure 3 and Figure 4. 

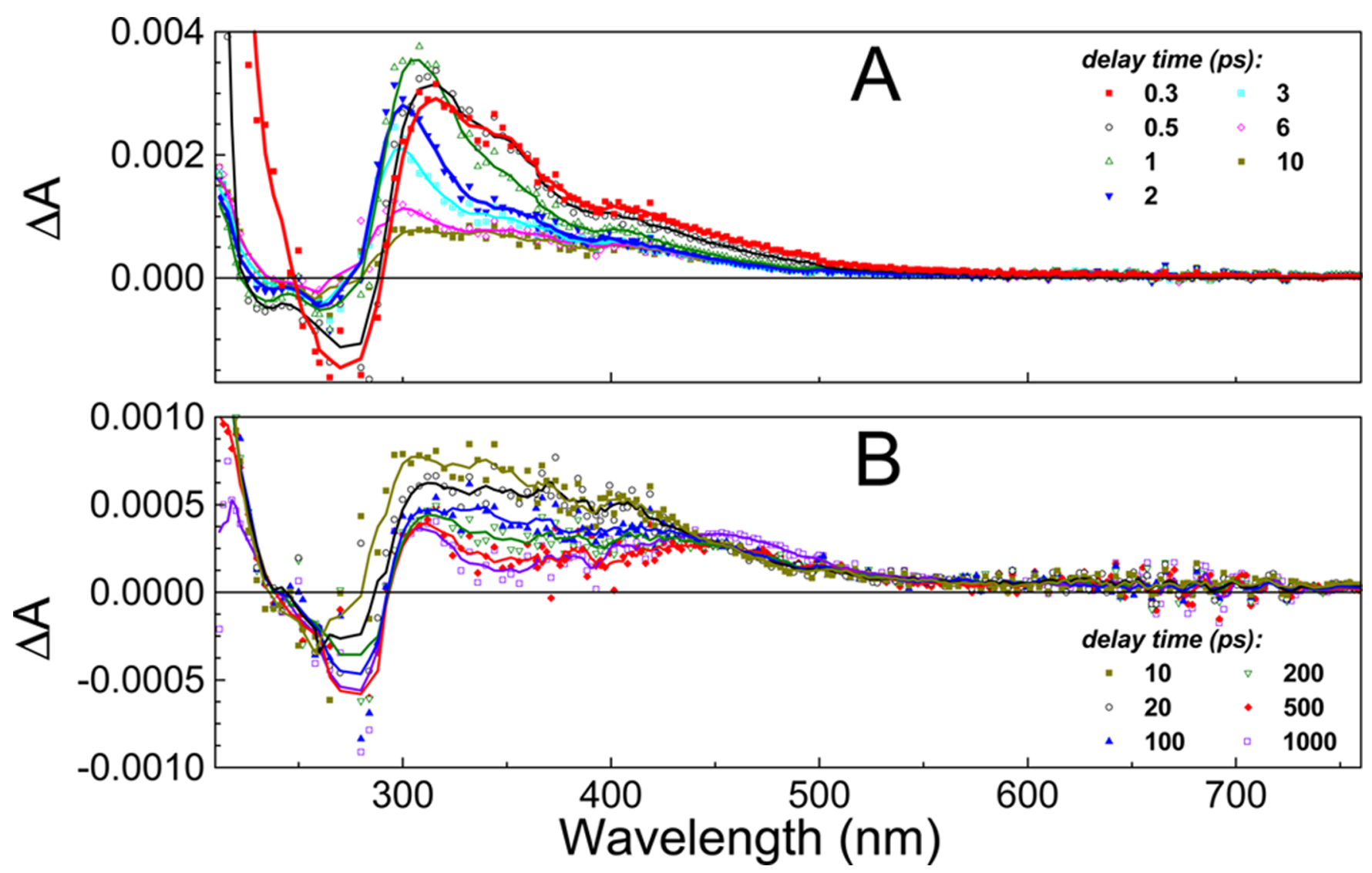

Figure 3. Transient absorption spectra of a $50 \mathrm{mM} \mathrm{Cu}\left(\mathrm{ClO}_{4}\right)_{2}-25 \mathrm{mM} \mathrm{LiCl}$ methanol solution measured at several delay times measured at several delay times following $255 \mathrm{~nm}$ excitation. Panels A and B show the short and long time delays, respectively.

Transient absorption spectra were also measured for the neat solvent under the same experimental conditions. The solvent signal becomes negligibly small starting from the delay time of 0.5 ps for the deep-UV range of the transient absorption spectra $(212-250 \mathrm{~nm})$, and from $0.3 \mathrm{ps}$ for the near-IR range (250$760 \mathrm{~nm}$ ). For the delay time of $0.2 \mathrm{ps}$, the solvent signal is small relatively to the signal from the sample solution. The solvent contribution to the solution $\Delta A$ signal is reduced by a factor of 5 to a small/negligibly small level by using the sample with the large solute absorbance at the $255 \mathrm{~nm}$ excitation wavelength ( $A$ $=1.5)$. In the solution, the entire spectral evolution is dominated by the two broad positive absorption signals $(212-225$ and $300-550 \mathrm{~nm})$ and the broad negative signal (225-300 nm). These bands, although with some solvent contribution are already formed at the very short time (100 and 200 fs $\Delta A$ spectra, Supporting Information). Between 0.3 and 1 ps, the negative signal decays and reshapes. The broad absorption in the $300-550 \mathrm{~nm}$ range narrows and blue-shifts, leading to the band centered at $306 \mathrm{~nm}$. The spectral blue-shift of this band is accompanied by a partial cancellation of the ground-state bleach, and as a result, by the blue-shift of the $\Delta A$ $=0$ crossing point. Between 1 and $10 \mathrm{ps}$, the $212 \mathrm{~nm}$ band gradually develops (time constant, $1.9 \mathrm{ps}$ ), the ground-state bleach partially recovers (time constant, $\approx 0.6 \mathrm{ps}$ ), and the 306 $\mathrm{nm}$ band significantly decays (time constant, $\approx 1 \mathrm{ps}$ ), becoming again the broad band at 10 ps. Between 10 and 1000 ps, the 212 $\mathrm{nm}$ band decays (time constant, $>2 \mathrm{~ns}$ ) and the ground-state bleach recovers and reshapes (time constant, $>2 \mathrm{~ns}$ ). The blue wing $(300-450 \mathrm{~nm})$ of the broad $300-550 \mathrm{~nm}$ band decays (time constant, $170 \mathrm{ps}$ ), whereas the red part of this band does not change in the intensity between 10 and 500 ps, and even exhibits the rise between 500 and 1000 ps. The 1 ns $\Delta A$ spectrum consists of 212, 310, and $450 \mathrm{~nm}$ bands and the ground-state bleach.

The description of the time evolution of the selected $\Delta A$ kinetics traces shown in Figure 4 is obtained by fitting them to a sum of exponential functions and a permanent signal (Table $\mathrm{S} 1$, Supporting Information). The $214 \mathrm{~nm}$ kinetic trace is described by the four components: $\tau_{1}<0.5$ ps (rise, major), $\tau_{2}$ $\sim 1.9 \pm 0.2$ ps (rise, major), $\tau_{3} \sim 51$ ps (decay, minor), and $\tau_{4}$ $\sim 6000$ ps (decay, minor). The 234 nm kinetic trace displays four components: $\tau_{1}=0.7 \pm 0.1$ ps (negative signal rise, major), $\tau_{2}=3.8 \pm 0.5$ ps (negative signal decay, major), $\tau_{3}=$ $170 \pm 40 \mathrm{ps}$, and $\tau_{4} \sim 6000 \mathrm{ps}$ (negative signal decay, both minor, similar to $214 \mathrm{~nm}$ ). The $260 \mathrm{~nm}$ kinetic trace is described by the two components: $\tau_{1}=0.6 \pm 0.1 \mathrm{ps}$ (negative signal decay, major, similar to $234 \mathrm{~nm}$ ), and $\tau_{2} \sim 3000 \mathrm{ps}$. The exponential fit of the $312 \mathrm{~nm}$ kinetic trace demonstrates that the initial rise of the $\Delta A$ signal $\left(\tau_{1}=0.4 \pm 0.1 \mathrm{ps}\right)$ is followed by one major fast decay $\left(\tau_{2}=1.4 \pm 0.3 \mathrm{ps}\right)$ component and two slower minor decay components, $\tau_{3} \sim 13$ ps and $\tau_{4}=170 \pm 40$ ps. The $\Delta A$ time evolution at 350 and $400 \mathrm{~nm}$ is dominated by fast major decay $\left(\tau_{1}(350 \mathrm{~nm})=1.0 \pm 0.1 \mathrm{ps}, \tau_{1}(400 \mathrm{~nm})=0.6\right.$ $\pm 0.1 \mathrm{ps}$ ) followed by two minor decay components, $\tau_{2}=8 \pm 2$ ps, $\tau_{3}=170 \pm 50 \mathrm{ps}$ (similar to 234 and $312 \mathrm{~nm}$ ). At $475 \mathrm{~nm}$, the initial major decay, $\tau_{1}=0.38 \pm 0.01 \mathrm{ps}$, which at this wavelength is even faster than at 350 and $400 \mathrm{~nm}$, is followed by a slow, minor rise, $\tau_{2} \sim 3000$ ps.

3.2.2. Acetonitrile. Ultrafast time-resolved transient absorption $\Delta A$ spectra and corresponding kinetic traces following 266 


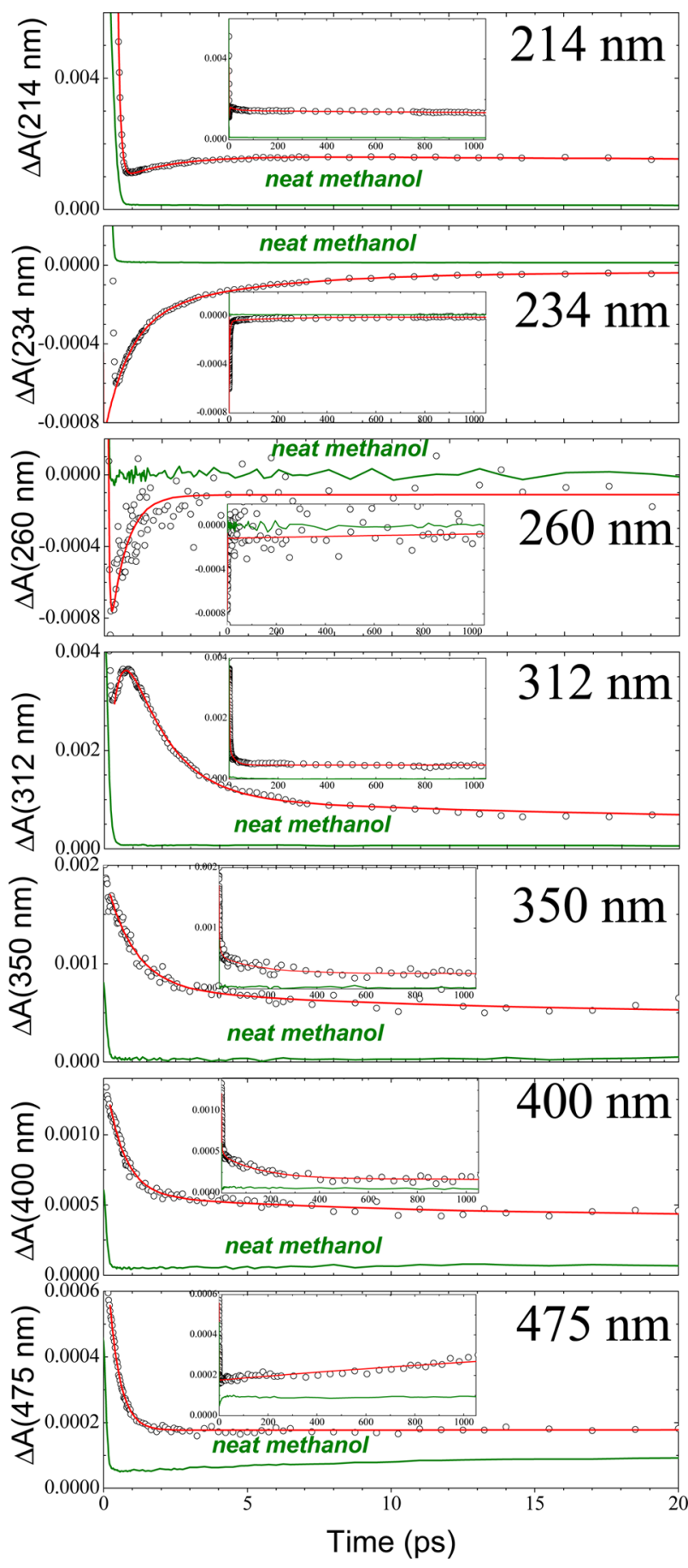

Figure 4. Short-time transient absorption kinetic traces (symbols) of a $50 \mathrm{mM} \mathrm{Cu}\left(\mathrm{ClO}_{4}\right)_{2}-25 \mathrm{mM} \mathrm{LiCl}$ methanol solution following $255 \mathrm{~nm}$ excitation measured at probe wavelengths of $214,234,260,312,350$, 400 , and $475 \mathrm{~nm}$ shown in legends. Multiexponential fits (red lines) and short-time $\Delta A$ signals measured in neat methanol under the identical experimental conditions (green lines) are also shown. The insets display the same $\Delta A$ kinetic traces measured up to $1 \mathrm{~ns}$.

$\mathrm{nm}$ excitation of $50 \mathrm{mM} \mathrm{Cu}\left(\mathrm{ClO}_{4}\right)_{2}-25 \mathrm{mM} \mathrm{NEt}_{4} \mathrm{Cl}$ acetonitrile solutions are shown in Figures 5 and 6. The solvent transient absorption spectra were also measured at the same experimental conditions. The solvent contribution to the solution $\Delta A$ data is negligibly small starting from the delay time of 0.8 ps for the deep-UV range of the transient absorption spectra $(212-230 \mathrm{~nm})$, from 0.5 ps for the UV range of the transient absorption spectra $(230-250 \mathrm{~nm})$, and from $0.3 \mathrm{ps}$ for the near-UV-vis range $(250-760 \mathrm{~nm})$. Similarly to copper(II) monochlorocomlexes in methanol, the entire spectral evolution of copper(II) monochlorocomplexes in acetonitrile is dominated by two broad positive transient absorption signals $(212-250 \mathrm{~nm}$ and $320-800 \mathrm{~nm})$ and the negative signal $(250-320 \mathrm{~nm})$, which are present already at very short times after excitation (100 and 200 fs, Supporting Information). The 0.3 ps $\Delta A$ spectrum consists of the $212 \mathrm{~nm}$ band, the ground-state bleach peaking at $290 \mathrm{~nm}$, and the broad $320-760 \mathrm{~nm}$ signal. Between 0.3 and $1 \mathrm{ps}$, the transient absorption spectra do not demonstrate significant changes. Between 1 and $10 \mathrm{ps}$, the $212 \mathrm{~nm}$ band gradually decays (time constant, $8 \mathrm{ps}$ ), and ground-state bleach partially recovers (time constant, $2.4 \mathrm{ps}$ ). During the same time period, the $320-760$ $\mathrm{nm}$ broad signal decays, narrows, and blue-shifts forming the $330 \mathrm{~nm}$ band with the $400 \mathrm{~nm}$ shoulder, Figure 5. The blueshift of this band probably partially cancels the ground-state bleach. Between 10 and 1000 ps, the minor decay of the 212 $\mathrm{nm}$ band is accompanied by partial ground state bleach recovery (time constant $\sim 200 \mathrm{ps}$ ). The $330 \mathrm{~nm}$ band significantly decays (time constant, $\sim 200 \mathrm{ps}$ ) and reshapes to become again broad at $500 \mathrm{ps}$. The $1 \mathrm{~ns} \Delta A$ spectrum shows the $212 \mathrm{~nm}$ band, the broad $330-760 \mathrm{~nm}$ induced absorption, and the ground-state bleach.

The description of the temporal evolution of the $\Delta A$ spectra at several selected wavelengths is shown in (Figure 6, main text and Table S1, Supporting Information). Similar to the case of methanol solutions, a sum of exponential functions (from two to four) and an offset adequately describes the selected $\Delta A$ kinetic traces. At $225 \mathrm{~nm}$, the best-fit time constants obtained were $\tau_{2} \sim 7.8 \pm 0.2 \mathrm{ps}$ (decay, minor) and $\tau_{3} \sim 160 \pm 40 \mathrm{ps}$ (decay, minor), whereas $\tau_{1}$ could not be resolved because of the solvent contribution. The $290 \mathrm{~nm}$ kinetic trace is described by the two components: $\tau_{1}=2.4 \pm 0.1$ ps (negative signal decay, major) and $\tau_{2}=260 \pm 70 \mathrm{ps}$ (negative signal decay, major, similar to $225 \mathrm{~nm}$ ). The $330 \mathrm{~nm}$ kinetic trace consists of three components: $\tau_{1}=0.9 \pm 0.1$ ps (rise, major), $\tau_{2}=3.0 \pm 0.2 \mathrm{ps}$ (decay, major), and $\tau_{3}=210 \pm 10$ ps (decay, major, similar to 225 and $290 \mathrm{~nm}$ ). Upon going to longer wavelengths, the amplitudes of the fast rise and decay major components decrease. Thus, the initial rise in the $360,400,500$, and $600 \mathrm{~nm}$ kinetic traces $\left(\tau_{1}(360 \mathrm{~nm})=0.8 \pm 0.1 \mathrm{ps}, \tau_{1}(400 \mathrm{~nm})=0.39 \pm\right.$ $\left.0.05 \mathrm{ps}, \tau_{1}(500 \mathrm{~nm})=0.17 \pm 0.05 \mathrm{ps}, \tau_{1}(600 \mathrm{~nm})<0.15 \mathrm{ps}\right)$ is followed by one major fast decay component $\left(\tau_{2}(360 \mathrm{~nm})=\right.$ $2.1 \pm 0.1 \mathrm{ps}, \tau_{2}(400 \mathrm{~nm})=1.7 \pm 0.1 \mathrm{ps}, \tau_{2}(500 \mathrm{~nm})=1.1 \pm$ $\left.0.1 \mathrm{ps}, \tau_{2}(600 \mathrm{~nm})=0.75 \pm 0.05 \mathrm{ps}\right)$ and two slower minor decay components, $\tau_{3} \sim 13 \mathrm{ps}$ and $\tau_{4} \sim 210 \mathrm{ps}$.

3.3. Charge Transfer Complexes of the Chlorine Atom with the Solvent. To identify the presence of a chlorine atom in the time-resolved spectra of copper(II) monochlorocompexes in methanol and acetonitrile, the knowledge of the absorption of the subsequent $\mathrm{MeOH} \cdot \mathrm{Cl}$ and $\mathrm{MeCN} \cdot \mathrm{Cl}$ chargetransfer $(\mathrm{CT})$ complexes is required. The absorption spectrum of $\mathrm{MeOH} \cdot \mathrm{Cl} \mathrm{CT}$ complex was adopted from previous work, ${ }^{31}$ where chloroacetone was used as a photochemical precursor of $\mathrm{Cl}$ atoms. In the current work in acetonitrile solutions, we also used photolysis of chloroacetone precursor to obtain the absorption spectrum of a MeCN.Cl CT complex, Figure 6S, Supporting Information. By analogy with chloroacetone in methanol, the broad $320-370 \mathrm{~nm}$ band in the 500 ps $\Delta A$ spectrum of chloroacetone in acetonitrile upon $266 \mathrm{~nm}$ excitation was assigned to a $\mathrm{MeCN} \cdot \mathrm{Cl} \mathrm{CT}$ complex. The 

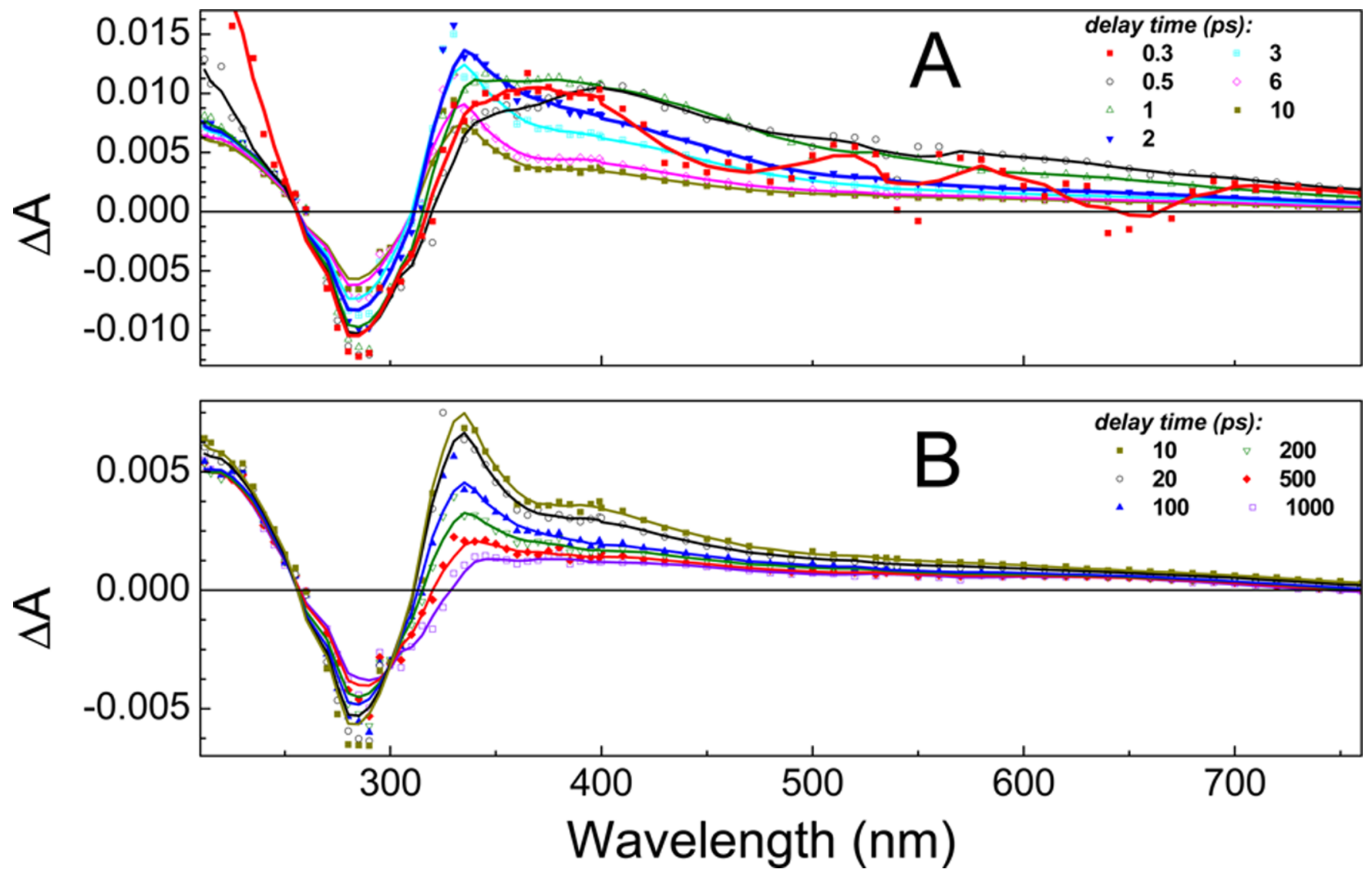

Figure 5. Transient absorption spectra of a $50 \mathrm{mM} \mathrm{Cu}\left(\mathrm{ClO}_{4}\right)_{2}-25 \mathrm{mM} \mathrm{NEt}_{4} \mathrm{Cl}$ acetonitrile solution measured at several delay times following 266 $\mathrm{nm}$ excitation. Panels A and B show the short and long time delays, respectively.

extinction coefficient at the absorption maximum of the $\mathrm{Cl}$. $\mathrm{MeCN}$ CT complex was assumed to be equal to that reported for the $\mathrm{Cl} \cdot \mathrm{H}_{2} \mathrm{O}^{62}$ and $\mathrm{Cl} \cdot \mathrm{MeOH}^{31} \mathrm{CT}$ complexes, $4000 \mathrm{M}^{-1}$ $\mathrm{cm}^{-1}$ Figure 7 .

\section{DISCUSSION}

4.1. Electronic Absorption Spectra. A copper(II) cation exists in methanol solutions as $\left[\mathrm{Cu}^{\mathrm{II}}(\mathrm{MeOH})_{6}\right]^{2+}$, a distorted octahedral complex with local environment symmetry of $D_{4 h}{ }^{54}$ and as $\left[\mathrm{Cu}^{\mathrm{II}}(\mathrm{MeCN})_{4}\right]^{2+}$, a flattened tetrahedral complex with local environment symmetry of $\mathrm{D}_{2 \mathrm{~d}}$ in acetonitrile solutions. ${ }^{55,56}$ Substitution of one of the solvent molecules by a chloride ion does not change significantly the geometry of the resulting chlorocomplexes. ${ }^{56}$ The electronic absorption spectra of the copper(II) complexes consist of highly intense UV bands corresponding to LMCT transitions, and near-IR bands of much lower intensity assigned to orbitally forbidden LF transitions between the $d$ orbitals of a copper ion. ${ }^{31,57,58}$ The coordination number and the substitution number significantly affect the electronic spectra of copper(II) chlorocomplexes. Thus, the electronic spectra of methanol chlorocomplexes $\left[\mathrm{Cu}^{\mathrm{II}}(\mathrm{MeOH})_{6-n} \mathrm{Cl}_{n}\right]^{2-n}$ (coordination number six) $)^{57,58}$ are more similar to aqua chlorocomplexes $\left[\mathrm{Cu}^{\mathrm{II}}\left(\mathrm{H}_{2} \mathrm{O}\right)_{6-n} \mathrm{Cl}_{n}\right]^{2-n}$ (coordination number six), ${ }^{63}$ that is with the equal substitution number $n$, than with acetonitrile chlorocomplexes $\left[\mathrm{Cu}^{\mathrm{II}}(\mathrm{MeCN})_{4-n} \mathrm{Cl}_{n}\right]^{2-n}$ (coordination number four), both for LMCT and LF bands. The effect of the substitution number can be easily observed from the electronic spectra of methanol and acetonitrile copper(II) complexes, Figure 1. The red shift of the LF bands with the increase of the substitution number can be easily explained based on the position of the methanol, acetonitrile molecules and the chloride ion in the spectrochemical series of ligands $\left(\mathrm{Cl}^{-}<\mathrm{MeOH}<\mathrm{CH}_{3} \mathrm{CN}\right){ }^{64-68}$

Copper(II) monochlorococomlexes in methanol, $\left[\mathrm{Cu}^{\mathrm{II}}(\mathrm{MeOH})_{5} \mathrm{Cl}\right]^{2+}$, and in acetonitrile, $\left[\mathrm{Cu}^{\mathrm{II}}(\mathrm{MeCN})_{3} \mathrm{Cl}\right]^{2+}$, have the distorted octahedral $\mathrm{C}_{4 v}$ and the distorted square planar $D_{2 d}$ symmetries, respectively. In the ligand fields of $C_{4 v}$ and $D_{2 d}$ symmetries, five degenerate d-orbitals of an isolated copper(II) ion split into four energy levels, one of them is double-degenerate in energy. A copper(II) ion has $d^{9}$ configuration, and, therefore, three lower $\mathrm{d}-\mathrm{d}$ orbitals are fully occupied, and there is one vacant position at the highest $\mathrm{d}-\mathrm{d}$ molecular orbital. As a result, for these complexes one should observe three LF bands, and three LF excited states are possible. It is important to note that LF and LMCT excited state has the same multiplicity as the ground electronic state (one unpaired electron-multiplicity is doublet).

In methanol and acetonitrile solutions upon 255 and $266 \mathrm{~nm}$ excitation, respectively, copper(II) monochlorocomplexes (Figure 2) are predominately excited into the LMCT band. In methanol, upon $255 \mathrm{~nm}$ excitation $\left[\mathrm{Cu}^{\mathrm{II}}(\mathrm{MeOH})_{5} \mathrm{Cl}\right]^{+}$, $\left[\mathrm{Cu}^{\mathrm{II}}(\mathrm{MeOH})_{6}\right]^{2+}$, and $\left[\mathrm{Cu}^{\mathrm{II}}(\mathrm{MeOH})_{4} \mathrm{Cl}_{2}\right]$ complexes are excited in a ratio of 1.0:0.33:0.16. In acetonitrile, upon 266 $\mathrm{nm}$ excitation $\left[\mathrm{Cu}^{\mathrm{II}}(\mathrm{MeCN})_{3} \mathrm{Cl}\right]^{+}, \quad\left[\mathrm{Cu}^{\mathrm{II}}(\mathrm{MeCN})_{4}\right]^{2+}$, and $\left[\mathrm{Cu}^{\mathrm{II}}\left(\mathrm{MeCN}_{2} \mathrm{Cl}_{2}\right]\right.$ complexes are excited in a ratio of 1.0:0.11:0.12. The aforementioned ratios are obtained based on the relative absorbance of these complexes in solution. As we have shown in the previous work, ${ }^{31}$ excitation of small amounts of the unsubstituded and disubstituted copper(II) 


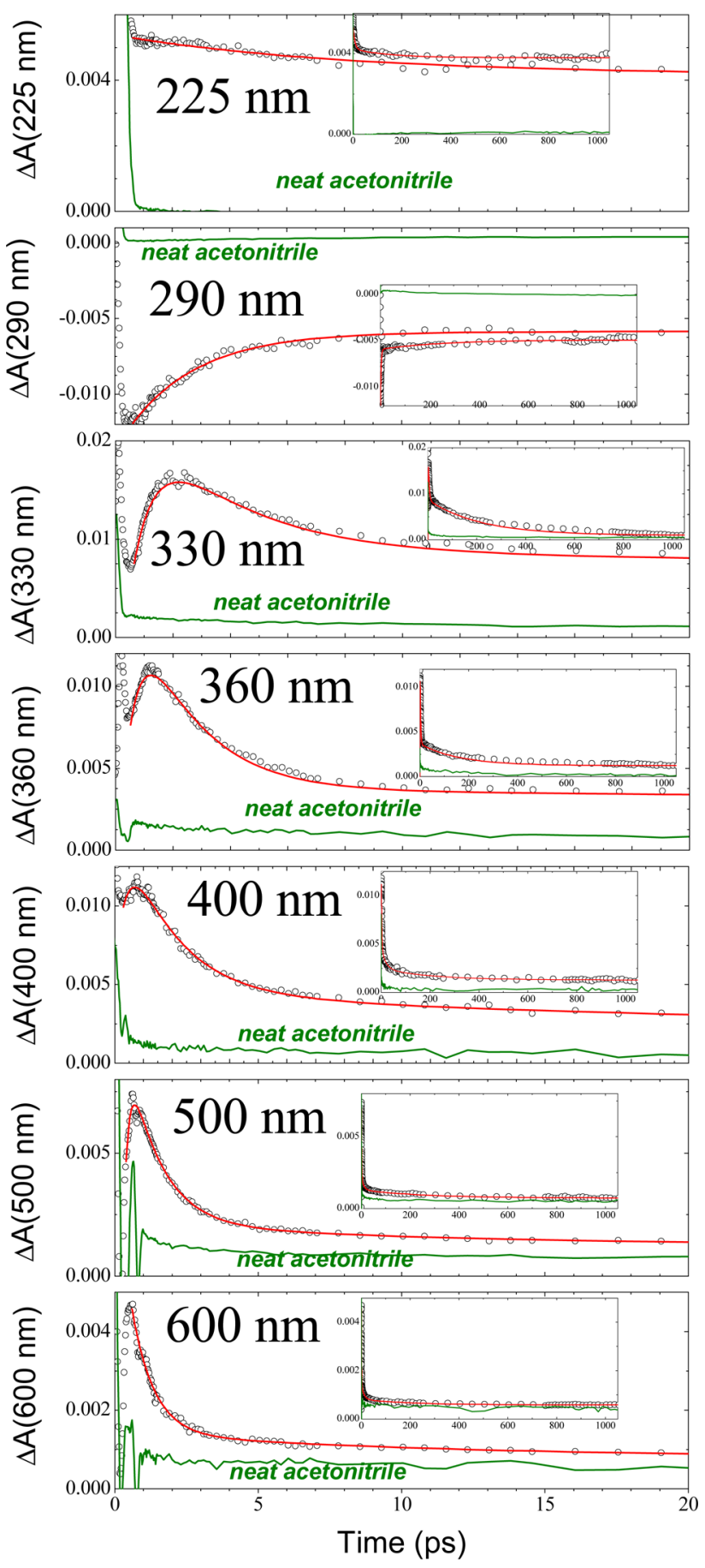

Figure 6. Short-time transient absorption kinetic traces (symbols) of a $50 \mathrm{mM} \mathrm{Cu}\left(\mathrm{ClO}_{4}\right)_{2}-25 \mathrm{mM} \mathrm{NEt}_{4} \mathrm{Cl}$ acetonitrile solution following $266 \mathrm{~nm}$ excitation measured at probe wavelengths of 225, 290, 330, $360,400,500$, and $600 \mathrm{~nm}$ shown in legends. The insets display the same $\Delta A$ kinetic traces measured up to long time delays. Multiexponential fits (red lines) of the acquired data and short-time $\Delta A$ signals measured in neat methanol for the same experimental conditions (green lines) are also shown. The insets display the same $\Delta A$ kinetic traces measured up to long time delays.

chlorocomplexes does not affect the observed transient absorption dynamics.

4.2. Assignment of Transient Absorption. In our previous work $^{31}$ we have shown that the UV part of the transient absorption spectra of copper(II) monochlorocomplex

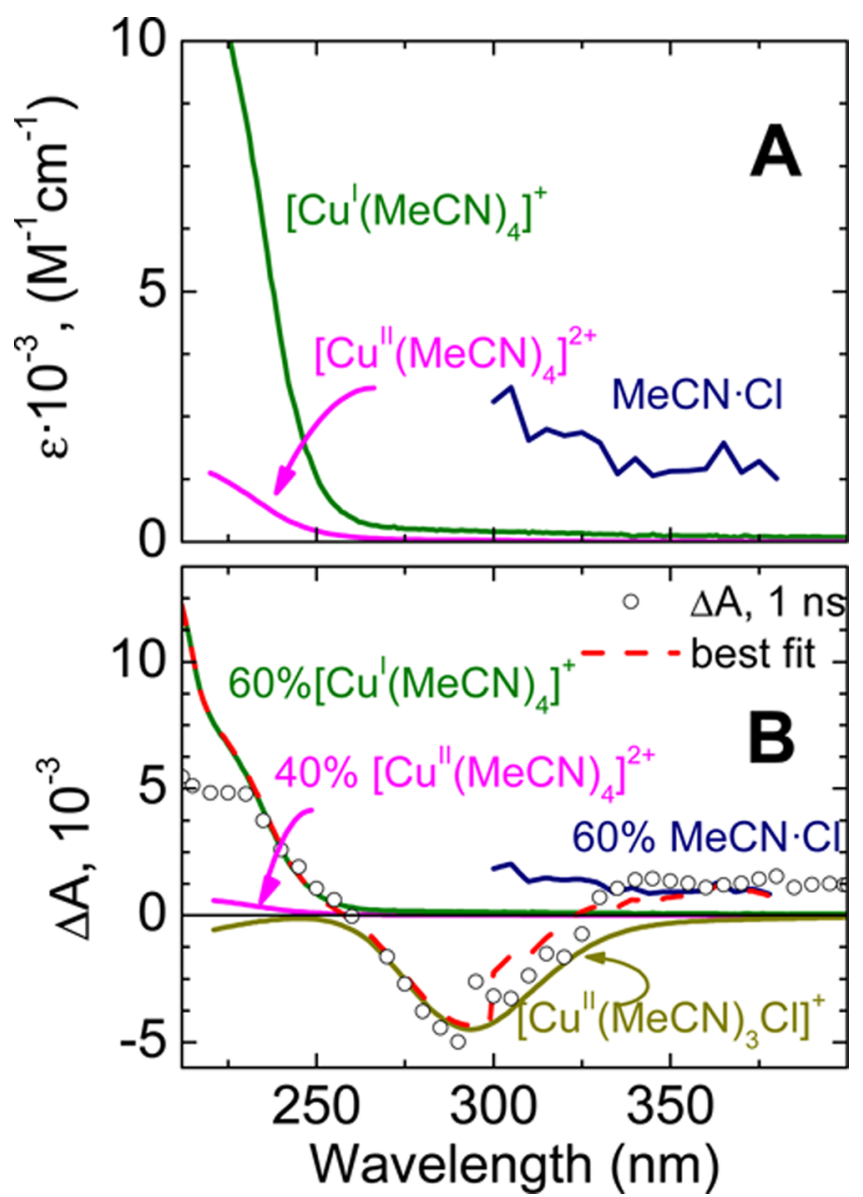

Figure 7. Panel A: absorption spectra of $\mathrm{Cl} \cdot \mathrm{MeCN} \mathrm{CT}$ complexes, $\left[\mathrm{Cu}^{\mathrm{II}}(\mathrm{MeCN})_{4}\right]^{2+}$, and $\left[\mathrm{Cu}^{\mathrm{I}}(\mathrm{MeCN})_{4}\right]^{+}$complexes in acetonitrile obtained as described in the text. The extinction coefficient at the absorption maximum of the $\mathrm{Cl} \cdot \mathrm{MeCN} \mathrm{CT}$ complex was assumed to be $4000 \mathrm{M}^{-1} \mathrm{~cm}^{-1}$ equal to that reported for the $\mathrm{Cl} \cdot \mathrm{H}_{2} \mathrm{O}^{62}$ and $\mathrm{Cl}$. $\mathrm{MeOH}^{31} \mathrm{CT}$ complexes. Panel B: fit of the UV part of the $1000 \mathrm{ps}$ transient absorption spectrum of a $50 \mathrm{mM} \mathrm{Cu}\left(\mathrm{ClO}_{4}\right)_{2}-25 \mathrm{mM}$ $\mathrm{NEt}_{4} \mathrm{Cl}$ acetonitrile solution to the spectra of $\mathrm{Cl} \cdot \mathrm{MeCN} \mathrm{CT}$, $\left[\mathrm{Cu}^{\mathrm{II}}(\mathrm{MeCN})_{4}\right]^{2+}$, and $\left[\mathrm{Cu}^{\mathrm{I}}(\mathrm{MeCN})_{4}\right]^{+}$and the steady-state absorption spectra of $\left[\mathrm{Cu}^{\mathrm{II}}(\mathrm{MeCN})_{3} \mathrm{Cl}\right]^{+}$.

is dominated at the short time after LMCT photoexcitation by the vibrationally hot electronic ground state $\left[\mathrm{Cu}^{\mathrm{II}}(\mathrm{MeOH})_{5} \mathrm{Cl}\right]^{+}$complex, which absorbs at $310-384 \mathrm{~nm}$, ground-state bleach of the $\left[\mathrm{Cu}^{\mathrm{II}}(\mathrm{MeOH})_{5} \mathrm{Cl}\right]^{+}$complex $(230-$ $290 \mathrm{~nm})$ and the overcoordinated copper(I) complex $\left(\left[\mathrm{Cu}^{\mathrm{I}}(\mathrm{MeOH})_{5}\right]^{+}\right.$absorbing in the $212-230 \mathrm{~nm}$ range $)$. The latter complex is formed as a product of radical dissociation of the initial $\left[\mathrm{Cu}^{\mathrm{II}}(\mathrm{MeOH})_{5} \mathrm{Cl}\right]^{+}$complex (Figure 3 ). The intermediate- and long-time $\Delta A$ spectra (the UV part) are dominated by the ground state bleach of the equilibrated mixture of the copper(II) chlorocomplexes (240-290 nm), the absorption of radical dissociation products, the copper(I) solvatocomplex $\left(\left[\mathrm{Cu}^{\mathrm{I}}(\mathrm{MeOH})_{4}\right]^{+}, 212-240 \mathrm{~nm}\right)$, and the absorption of the $\mathrm{Cl} \cdot \mathrm{MeOH}$ charge transfer (CT) complex (absorption maximum at $320 \mathrm{~nm}$ ). The absorption of the $\mathrm{Cl}$. $\mathrm{MeOH}$ CT complex overlaps the intense absorption of the vibrationally hot ground electronic state complex at short times after photoexcitation, and therefore, can be observed only after 10 ps. In the present work, transient absorption spectra have been measured in the extended broadband deep-UV-to-near-IR $(212-760 \mathrm{~nm})$ spectral probing range. The UV-part of the 
transient absorption spectra is similar to the previously published data, ${ }^{31}$ and therefore the above-mentioned spectral assignments have been used for the $\Delta A$ data. When probing in the extended spectral range, one can observe the weak transient absorption signals in the visible range (400-550 nm), which are revealed as a shoulder of the $320 \mathrm{~nm}$ transient absorption band at the short and intermediate delay times. At long times starting from $100 \mathrm{ps}$, the $\Delta A$ signals reshape forming the transient absorption band with the maximum at $410 \mathrm{~nm}$, which then shifts to $450 \mathrm{~nm}$ at $1 \mathrm{~ns}$. The number of possible photoproducts $\left(\left[\mathrm{Cu}^{\mathrm{II}}(\mathrm{MeOH})_{5}\right]^{2+},\left[\mathrm{Cu}^{\mathrm{I}}(\mathrm{MeOH})_{5}\right]^{+}\right.$, $\left[\mathrm{Cu}^{\mathrm{I}}(\mathrm{MeOH})_{4}\right]^{+}$, and $\left.\mathrm{Cl} \cdot \mathrm{MeOH}, \mathrm{Cl}^{-}\right)$can be ruled out because all these species absorb in the UV range. In addition, the vibrationally hot electronic ground state because vibrational relaxation occurs at the much faster time scale for small molecules in polar solvent, ${ }^{31,47,49}$ and the LMCT excited state due to its repulsive nature, ${ }^{25,26,70}$ and, as a result, the short lifetime, both can be ruled out. The possible assignments of the visible part of the transient absorption spectra are the LF excited states and a $\mathrm{Cu}(\mathrm{I}) \cdots{ }^{\bullet} \mathrm{CH}_{2} \mathrm{OH}$ complex. The formation of the LF exciplexes of copper(II) porphyrins with Lewis bases, such as pyridine and pyridine derivatives was reported by Liu and coauthors. ${ }^{40}$ The observed absorption corresponds to the electronic transitions from the LF states to the LMCT states, and therefore, the extinction coefficient of these bands should be comparable with the extinction coefficient of the LMCT bands in the ground state spectrum. Indeed, we observed that the visible signal has the same order of magnitude as the ground state bleach signal. Additionally, a $\sim 3$ ns rise of the 460 $\mathrm{nm}$ band was observed as well as the isosbestic point at $440 \mathrm{~nm}$. This observation demonstrates that the decay of the $\mathrm{Cl} \cdot \mathrm{MeOH}$ CT complex is accompanied by the formation of species peaking at $460 \mathrm{~nm}$. The nanosecond flash-photolysis and pulseradiolysis of the copper(II) chloride complexes in frozen ethanol matrices at $77 \mathrm{~K}^{71-73}$ has demonstrated the formation of the complexes between the copper(I) solvatocomplex and the $\mathrm{CH}_{3} \mathrm{CH} \cdot \mathrm{OH}$ radicals, $\mathrm{Cu}(\mathrm{I}) \cdots \mathrm{CH}_{3} \mathrm{CH} \mathrm{H}^{\bullet} \mathrm{OH}$. This complex exhibits the absorption maximum at $455 \mathrm{~nm}$. Therefore, the $460 \mathrm{~nm}$ band can be assigned to the $\mathrm{Cu}(\mathrm{I}) \cdots{ }^{\bullet} \mathrm{CH}_{2} \mathrm{OH}$ complex by the analogy with ethanol solutions. Indeed, these species is probably formed as a result of the reaction of the photochemically formed chlorine atom and methanol molecule ligand of the copper(I) solvatocomplex byproduct: $\left[\mathrm{Cu}^{\mathrm{I}}\left(\mathrm{CH}_{3} \mathrm{OH}\right)_{4}\right]^{+}+$ $\mathrm{Cl}^{\bullet}=\left[\mathrm{Cu}^{\mathrm{I}} \mathrm{CH}_{2} \mathrm{OH}\left(\mathrm{CH}_{3} \mathrm{OH}\right)_{3}\right]^{+}+\mathrm{HCl}$.

The time evolution and the spectral shape of transient absorption spectra of copper(II) monochlorocomplex in acetonitrile, $\left[\mathrm{Cu}{ }^{\mathrm{II}}(\mathrm{MeCN})_{3} \mathrm{Cl}\right]^{+}$, have a lot of similarities with that in methanol (Figure 5). The short time spectra are dominated by two positive signals, the $212 \mathrm{~nm} \Delta A$ band and the broad $\Delta A$ spectrum from 315 to $760 \mathrm{~nm}$, and the negative ground-state bleach with the maximum at $285 \mathrm{~nm}$. The significant spectral narrowing and blue shift of the 315-760 nm $\Delta A$ signal on a time scale $0.3-10 \mathrm{ps}$ is evidence of the vibrational relaxation. ${ }^{69}$ The $315-760 \mathrm{~nm}$ signal decay is accompanied by the ground state bleach recovery. This observation demonstrates that the short-time broad $\Delta A$ signal is ought to be assigned to the absorption of the vibrationally hot ground electronic state of the initial complex. The vibrational relaxation is characterized by $\tau_{1}$ and $\tau_{2}$ exponential components of the kinetic traces in the $330-760 \mathrm{~nm}$ spectral range, $1-13 \mathrm{ps}$, and is complete at $20 \mathrm{ps}$. At the same time, the $212 \mathrm{~nm}$ band somewhat decays (time constant, $7.8 \mathrm{ps}$ ). This occurs without any spectral shift, and therefore, this band should be assigned to vibrationally relaxed photoproduct. The $212 \mathrm{~nm}$ band can be attributed to products of the either ionic $\left(\left[\mathrm{Cu}^{\mathrm{II}}(\mathrm{MeCN})_{3}\right]^{2+}\right.$ or $\left.\left[\mathrm{Cu}^{\mathrm{II}}(\mathrm{MeCN})_{4}\right]^{2+}\right)$ or radical $\left(\left[\mathrm{Cu}^{\mathrm{I}}(\mathrm{MeCN})_{3}\right]^{+}\right.$or $\left.\left[\mathrm{Cu}^{\mathrm{I}}(\mathrm{MeCN})_{4}\right]^{+}\right)$dissociation, Figure $7 \mathrm{~A}$. The 7.8 ps decay time constant corresponds to the addition of the acetonitrile molecules to the initially formed undercoordinated copper(II) and copper(I) photoproducts: $\left[\mathrm{Cu}^{\mathrm{II}}(\mathrm{MeCN})_{3}\right]^{2+}+\mathrm{MeCN}=\left[\mathrm{Cu}^{\mathrm{II}}(\mathrm{MeCN})_{4}\right]^{2+}$, $\left[\mathrm{Cu}^{\mathrm{I}}(\mathrm{MeCN})_{3}\right]^{+}+\mathrm{MeCN}=\left[\mathrm{Cu}^{\mathrm{I}}(\mathrm{MeCN})_{4}\right]^{+}$, where the stable four-coordinated solvatocomplexes have the smaller extinction coefficients than the initially formed three-coordinated complexes. This assignment is supported by the analysis of the $1 \mathrm{~ns} \Delta \mathrm{A}$ spectrum, Figure $7 \mathrm{~B}$. Under the assumption that the contribution of the photoproducts of ionic and radical dissociation into the $1 \mathrm{~ns} \Delta A$ spectrum is major, the $1 \mathrm{~ns} \Delta A$ spectrum can be fitted as a sum of absorption of $\left[\mathrm{Cu}^{\mathrm{II}}(\mathrm{MeCN})_{4}\right]^{2+},\left[\mathrm{Cu}^{\mathrm{I}}(\mathrm{MeCN})_{4}\right]^{+}$, the $\mathrm{MeCN} \cdot \mathrm{Cl} \mathrm{CT}$ complex, and $\left[\mathrm{Cu}^{\mathrm{II}}(\mathrm{MeCN})_{3} \mathrm{Cl}\right]^{+}$. The best fit of the $\Delta A$ spectrum shows that $60 \%$ of the parent complexes dissociate into $\left[\mathrm{Cu}^{\mathrm{I}}(\mathrm{MeCN})_{4}\right]^{+}+\mathrm{Cl} \cdot \mathrm{MeCN}$, and $40 \%$ of the $\left[\mathrm{Cu}^{\mathrm{II}}(\mathrm{MeCN})_{3} \mathrm{Cl}\right]^{+}$form $\left[\mathrm{Cu}{ }^{\mathrm{II}}(\mathrm{MeCN})_{4}\right]^{2+}+\mathrm{Cl}^{-}$. The explanation of the $10-1000$ ps spectral evolution is rather complex. We note that in contrast to the copper(II) monochlorocomplex in methanol, the negative bleach reshaping is not observed for the intermediate and the long delay times $(10-1000 \mathrm{ps})$ in acetonitrile solutions. This suggests the absence of the re-equlibration process. A possible reason for this phenomena is that an unsubstituted complex $\left[\mathrm{Cu}(\mathrm{MeCN})_{4}\right]^{2+}$ is initially formed as a photodissociation product, and the contribution of the disubstuted complex into the absorption spectrum is too small to be observed through the recovery reaction $\left[\mathrm{Cu}^{\mathrm{II}}(\mathrm{MeCN})_{2} \mathrm{Cl}_{2}\right]^{2+}+\mathrm{MeCN}=$ $\left[\mathrm{Cu}^{\mathrm{II}}(\mathrm{MeCN})_{3} \mathrm{Cl}\right]^{2+}+\mathrm{Cl}^{-}$(Figure 2). The observation of two isosbestic points at 255 and $300 \mathrm{~nm}$ for the $10-1000 \mathrm{ps}$ $\Delta A$ spectra is evidence of a single dominating process on this time scale. This process is characterized by the longest time constant, about 200 ps. The recombination process $\left[\mathrm{Cu}^{\mathrm{I}}(\mathrm{MeCN})_{4}\right]^{+}+\mathrm{Cl} \cdot \mathrm{MeCN}=\left[\mathrm{Cu}^{\mathrm{II}}(\mathrm{MeCN})_{3} \mathrm{Cl}\right]^{2+}+$ $2 \mathrm{MeCN}$ is ruled out because the $\mathrm{Cl} \cdot \mathrm{MeCN} \mathrm{CT}$ complex, which should be responsible for the decay of the near-UV-vis $\Delta A$ signal, has no absorption at wavelengths longer than 400 $\mathrm{nm}$. Therefore, by analogy with the methanol solution, the LF excited state absorption contributes most to the 320-760 $\Delta A$ signal, somewhat contributes to the $212 \mathrm{~nm}$ band, and decays with a lifetime of about 200 ps as a result of relaxation to the electronic ground state. Interestingly, even the $1 \mathrm{~ns} \Delta A$ spectrum shows positive transient absorption in the visible range. This means that another LF excited state forms with the lifetime longer than $1 \mathrm{~ns}$, probably the lowest-energy LF state. It is important to note that the formation of $\mathrm{Cu}(\mathrm{I}) \cdots{ }^{\bullet} \mathrm{CH}_{2} \mathrm{CN}$ complex was not observed, because we did not observe any absorption maximum in the visible range or the picoseconds/ nanosecond rise component of the transient signal for wavelengths longer than $400 \mathrm{~nm}$. The acetonitrile molecule, $\mathrm{CH}_{3} \mathrm{CN}$, is less likely to be involved in alpha-hydrogen radical substitution reaction with a chlorine atom than methanol, $\mathrm{CH}_{3} \mathrm{OH}$, due to the inductive effect of the oxygen atom relatively to the nitrile carbon atom.

4.3. Mechanism. Upon $255 \mathrm{~nm}$ excitation, the copper(II) monochlorocomplex $\left[\mathrm{Cu}^{\mathrm{II}}(\mathrm{MeOH})_{5} \mathrm{Cl}\right]^{+}$in methanol solution is excited into the LMCT state (Figure 8). The populated LMCT state is repulsive, and therefore quickly $(<250 \mathrm{fs})$ undergoes internal conversion into vibrational hot ground and 


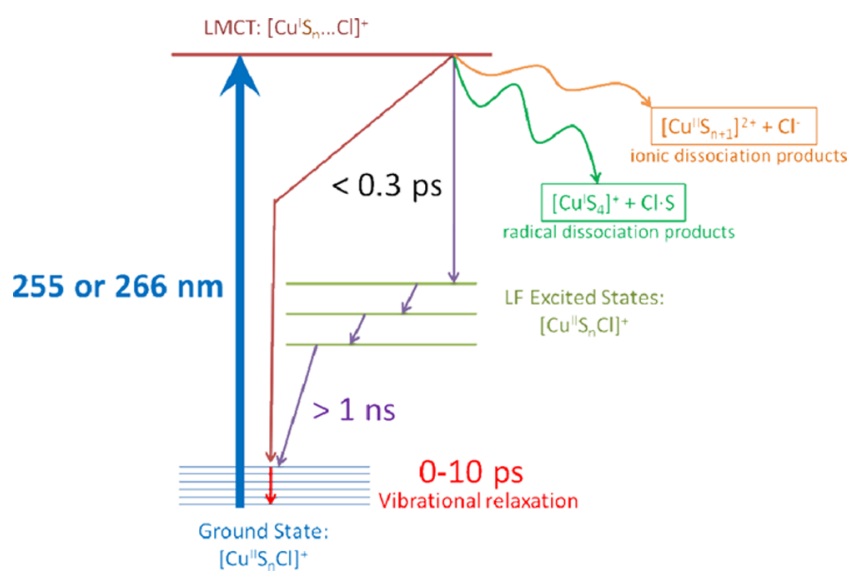

Figure 8. Proposed mechanism of the photodissociation of a $\left[\mathrm{Cu}(\mathrm{MeOH})_{5} \mathrm{Cl}\right]^{+}$complex in methanol and a $\left[\mathrm{Cu}^{\mathrm{II}}(\mathrm{MeCN})_{3} \mathrm{Cl}\right]^{+}$ complex in acetonitrile upon excitation into the LMCT states. Solvent molecules are marked as $\mathrm{S}$ in molecular formulas.

LF excited states or dissociates to form the copper(I) $\left[\mathrm{Cu}^{\mathrm{II}}(\mathrm{MeOH})_{5}\right]^{+}$solvatocomplex and the chlorine $\mathrm{Cl}$ atom. The overcoordinated $\left[\mathrm{Cu}^{\mathrm{I}}(\mathrm{MeOH})_{5}\right]^{+}$complex dissociates to form the stable $\left[\mathrm{Cu}^{\mathrm{I}}(\mathrm{MeOH})_{4}\right]^{+}$complex and the methanol molecule, $\tau_{2}(212 \mathrm{~nm})=2.2 \mathrm{ps}$, whereas the chlorine atom forms the charge-transfer complex, $\mathrm{Cl} \cdot \mathrm{MeOH} \mathrm{CTC}$. A minor fraction of the chlorine atoms reacts with the $\left[\mathrm{Cu}^{\mathrm{I}}(\mathrm{MeOH})_{4}\right]^{+}$ complexes by $\alpha$-hydrogen abstraction of the methanol ligand, forming the $\left[\mathrm{Cu}^{\mathrm{I}} \mathrm{CH}_{2} \mathrm{OH}\left(\mathrm{CH}_{3} \mathrm{OH}\right)_{3}\right]^{+}$complex, which has an absorption maximum at $460 \mathrm{~nm}$, and the $\mathrm{HCl}$ molecule. On the basis of the amplitudes of the ground-state bleach at $0.3 \mathrm{ps}$ and 1 ns delay times, we concluded that less than $3 \%$ of LMCT excited complexes dissociate, forming the photoproducts. Vibrational relaxation occurs at the time scale of several picoseconds, and is complete at $10 \mathrm{ps}$ after photoexcitation, as characterized by $\tau_{1}$ and $\tau_{2}$ in the $300-400 \mathrm{~nm}$ spectral range and $\tau_{1}$ at $475 \mathrm{~nm}$. A minor portion of the LMCT state species populates different LF excited states. On a picoseconds time scale, higher energy LF excited states relax to the lowest energy LF excited state, which is stable for much longer than $1 \mathrm{~ns}$. Photodepletion of the $\left[\mathrm{Cu}^{\mathrm{II}}(\mathrm{MeOH})_{5} \mathrm{Cl}\right]^{+}$complexes results in re-equlibration between other copper(II) complexes existing in the solution, $\left[\mathrm{Cu}^{\mathrm{II}}(\mathrm{MeOH})_{4} \mathrm{Cl}_{2}\right]$ and $\left[\mathrm{Cu}{ }^{\mathrm{II}}(\mathrm{MeOH})_{6}\right]^{2+}$, which is characterized by time constants of about 200 ps: $\tau_{3}$ in the $300-400 \mathrm{~nm}$ spectral range and $\tau_{3}(234 \mathrm{~nm})$, and several nanoseconds, $\tau_{4}(212,260 \mathrm{~nm})$.

Upon $266 \mathrm{~nm}$ excitation, the copper(II) monochlorocomplex $\left[\mathrm{Cu}^{\mathrm{II}}(\mathrm{MeCN})_{3} \mathrm{Cl}\right]^{+}$in acetonitrile solution is excited into the LMCT state. The excited species then relax either into vibrationally hot ground and LF excited states or dissociate into photoproducts (Figure 8). In acetonitrile, the photodissociation results in radical $\left(\left[\mathrm{Cu}^{\mathrm{I}}(\mathrm{MeCN})_{3}\right]^{+}+\mathrm{Cl} \cdot\right)$ and ionic $\left(\left[\mathrm{Cu}^{\mathrm{II}}(\mathrm{MeCN})_{3}\right]^{2+}+\mathrm{Cl}^{-}\right)$photoproducts. The initially formed copper complexes are undercoordinated, and the acetonitrile addition reactions are characterized by a 7.8 ps time constant, resulting in the formation of stable $\left[\mathrm{Cu}^{\mathrm{I}}(\mathrm{MeCN})_{4}\right]^{+}$and $\left[\mathrm{Cu}^{\mathrm{II}}(\mathrm{MeCN})_{4}\right]^{2+}$ complexes. At $1 \mathrm{~ns}$, the $\left[\mathrm{Cu}^{\mathrm{I}}(\mathrm{MeCN})_{4}\right]^{+}$and $\left[\mathrm{Cu}^{\mathrm{II}}(\mathrm{MeCN})_{4}\right]^{2+}$ complexes are present in solution in a ratio of 3:2. Similar to methanol solutions, chlorine atom products in acetonitrile forms $\mathrm{CT}$ complexes with the solvent, $\mathrm{Cl} \cdot \mathrm{MeCN}$. However, chlorine atoms do not react with the acetonitrile molecules, neither bulk or as ligand. On the basis of the amplitudes of the ground-state bleach signals at $0.3 \mathrm{ps}$ and $1 \mathrm{~ns}$ delay times, we concluded that about $50 \%$ of the LMCT excited complexes dissociate forming the photoproducts. The ensuing vibrational relaxation occurs on a time scale of several picoseconds, and is complete at 10 ps. A minor portion of the LMCT state species populates different LF excited states. The complexes in high energy LF excited states relax to the lowest energy LF excited state as well as to the ground state (a time constant of about $200 \mathrm{ps}$ ). The lowest energy excited state is stable for longer than than $1 \mathrm{~ns}$.

\section{CONCLUSIONS}

The photochemistry of copper(II) monochlorocomplexes is studied in methanol and acetonitrile solutions using femtosecond transient absorption spectroscopy with broadband deep-UV-to-near-IR probing $(212-760 \mathrm{~nm})$. Excitation of copper(II) monochlorocomplexes $\left[\mathrm{Cu}^{\mathrm{II}}(\mathrm{MeOH})_{6}\right]^{2+}$ in methanol at $255 \mathrm{~nm}$ and excitation of copper(II) monochlorocomplexes $\left[\mathrm{Cu}^{\mathrm{II}}(\mathrm{MeCN})_{4}\right]^{2+}$ in acetonitrile at $266 \mathrm{~nm}$ leads to the population of the LMCT electronic state. The complexes in the LMCT state are short-lived $(<250 \mathrm{fs})$ and decay either via internal conversion to lower-lying LF states or to the vibrationally hot ground electronic state. Vibrational relaxation occurs on a time scale of several picoseconds for both solvents. A minor fraction of the excited complexes relaxes to the relatively long-lived LF electronic excited states (lifetimes $>1$ ns). Copper(II) monochlorocomplexes excited to the LMCT state tend to undergo breaking of a $\mathrm{Cu}-\mathrm{Cl}$ bond. to Indeed, in methanol solutions, about $3 \%$ of the LMCT excited $\left[\mathrm{Cu}^{\mathrm{II}}(\mathrm{MeOH})_{5} \mathrm{Cl}\right]^{+}$complexes dissociate forming copper(I) solvatocomplexes, $\left[\mathrm{Cu}^{\mathrm{I}}(\mathrm{MeOH})_{4}\right]^{+}$, and chlorine atoms. In methanol, a radical $\mathrm{Cu}(\mathrm{I}) \ldots \mathrm{CH}_{2} \mathrm{OH}$ complex observed for the first time at the room temperature is formed as a result of the reaction between the photochemically formed chlorine atom and one of methanol molecule ligands of the copper(I) solvatocomplex byproduct: $\left[\mathrm{Cu}^{\mathrm{I}}\left(\mathrm{CH}_{3} \mathrm{OH}\right)_{4}\right]^{+}+\mathrm{Cl}^{\bullet}=$ $\left[\mathrm{Cu}^{\text {I॰ }} \mathrm{CH}_{2} \mathrm{OH}\left(\mathrm{CH}_{3} \mathrm{OH}\right)_{3}\right]^{+}+\mathrm{HCl}$.

In acetonitrile, about $50 \%$ of the LMCT excited $\left[\mathrm{Cu}^{\mathrm{II}}(\mathrm{MeCN})_{3} \mathrm{Cl}\right]^{+}$complexes undergo dissociation forming radical (copper(I) solvatocomplexes $\left[\mathrm{Cu}^{\mathrm{I}}(\mathrm{MeCN})_{4}\right]^{+}$and chlorine atoms) and ionic (copper(II) solvatocomplexes $\left[\mathrm{Cu}^{\mathrm{II}}(\mathrm{MeCN})_{4}\right]^{2+}$ and chloride ions) products in a ratio $3: 2$. The observation that the excited copper(II) monochlorocomplexes dissociate into the photoproducts much more efficiently in acetonitrile than in methanol can be explained in terms of the solvent structure. In methanol, strong hydrogen bond network formed by the solvent molecules results in the presence of the strong solvent cage around a parent complex. The solvent cage effect in methanol results in fast geminate recombination of initially formed product species, the copper(I) solvatocomplex $\left[\mathrm{Cu}^{\mathrm{I}}(\mathrm{MeOH})_{5}\right]^{+}$and the chlorine atom, resulting in only $3 \%$ of the initially excited complexes ending upas the long-live photoproducts. Acetonitrile does not form hydrogen bonds, and therefore, photoproducts more easily separate after formation. Another, albeit a minor, process observed only in methanol solution is the re-equilibration of the copper(II) complexes present in solutions (copper(II) solvatocomplexes and dichlorocomplexes), in which the equilibrium concentrations perturbed by excitation of the monochlorocomplexes recover on a sub-nanosecond to nanosecond time scale. Re-equilibration processes are not detected in acetonitrile. The unsubstituted $\left[\mathrm{Cu}^{\mathrm{II}}(\mathrm{MeCN})_{4}\right]^{2+}$ complex is initially formed as the photodissociation product, and the contribution of the disubstuted complex into the absorption 
spectrum is too small to observe the recovery reaction $\left[\mathrm{Cu}^{\mathrm{II}}(\mathrm{MeCN})_{2} \mathrm{Cl}_{2}\right]^{2+}+\mathrm{MeCN}=\left[\mathrm{Cu}^{\mathrm{II}}(\mathrm{MeCN})_{3} \mathrm{Cl}^{2+}+\mathrm{Cl}^{-}\right.$. This makes it difficult to observe the re-equilibration of copper(II) chlorocomplexes with a different number of chloride ligands in acetonitrile.

\section{ASSOCIATED CONTENT}

\section{S Supporting Information}

The Supporting Information is available free of charge on the ACS Publications website at DOI: 10.1021/acs.jpca.5b12509.

(i) Extended transient absorption $\Delta A$ spectra $(-0.1$ to $+1000 \mathrm{ps})$ of a $50 \mathrm{mMCu}\left(\mathrm{ClO}_{4}\right)_{2}-25 \mathrm{mM} \mathrm{LiCl}$ methanol solution and a $50 \mathrm{mM} \mathrm{Cu}\left(\mathrm{ClO}_{4}\right)_{2}-25 \mathrm{mM}$ $\mathrm{NEt}_{4} \mathrm{Cl}$ acetonitrile solution upon LMCT state excitation, where transient absorption $\Delta A$ spectra of the solvent are added for comparison, (ii) the fit of the UV part of the 1000 ps transient absorption spectrum of a 50 $\mathrm{mM} \mathrm{Cu}\left(\mathrm{ClO}_{4}\right)_{2}-25 \mathrm{mM} \mathrm{LiCl}$ methanol solution and the individual absorption spectra of photoproducts, $\mathrm{Cl}$. $\mathrm{MeOH} \mathrm{CT}$ complexes and $\left[\mathrm{Cu}^{\mathrm{I}}(\mathrm{MeOH})_{4}\right]^{+}$complexes in methanol, (iii) transient absorption spectra of a 500 $\mathrm{mM}$ chlororacetone solution in acetonitrile following 266 $\mathrm{nm}$ excitation, and (iv) best fit parameters of the of the selected kinetics traces of a $50 \mathrm{mMCu}\left(\mathrm{ClO}_{4}\right)_{2}-25$ $\mathrm{mMLiCl}$ methanol solution and a $50 \mathrm{mMCu}\left(\mathrm{ClO}_{4}\right)_{2}-$ $25 \mathrm{mM} \mathrm{NE}_{4} \mathrm{Cl}$ acetonitrile solution upon LMCT state excitation (PDF)

\section{AUTHOR INFORMATION}

\section{Corresponding Authors}

* Mailing address: Institute of Chemistry, Saint-Petersburg State University, 26 Universitetskiy pr., Petrodvorets, 198504 SaintPetersburg, Russian Federation. E-mail: a.mereshchenko@spbu. ru. Telephone: +7-951-677-5465.

*Mailing address: Department of Chemistry and the Center for Photochemical Sciences, Bowling Green State University, Bowling Green, OH 43403. E-mail: atarnov@bgsu.edu. Telephone: +1-419-372-3865.

\section{Author Contributions}

The manuscript was written through contributions of all authors. All authors have given approval to the final version of the manuscript.

\section{Notes}

The authors declare no competing financial interest.

\section{ACKNOWLEDGMENTS}

M.S.P. acknowledges the Saint-Petersburg State University for the financial support (Postdoctoral Fellowship No. 12.50.1189.2014). M.Yu.S. acknowledges Saint-Petersburg State University for financial support in the framework of Event 6, Grant 12.42.1270.2014. Optical measurements were performed at the Center for Optical and Laser Materials Research of the Saint-Petersburg State University and the Center for Photochemical Sciences, Bowling Green State University. This work was supported by the NSF CAREER (CHE-0847707, A.N.T.), NSF MRI (CHE-0923360, A.N.T.), Saint Petersburg State University research (2015-2017, 12.38.219.2015, V.A.K.), and RFBR (14-03-01003, 15-0305139, and 16-33-00646) awards. M.Z. acknowledges NSF Award CHE-1465052 for financial support. Discussions with Dr. A. G. Kudrev (Saint-Petersburg State University) and Prof.
V. F. Plyusnin (Voevodsky Institute of Chemical Kinetics and Combustion of SB RAS) are gratefully acknowledged.

\section{REFERENCES}

(1) Kochemirovsky, V. A.; Skripkin, M. Yu.; Tveryanovich, Yu. S.; Mereshchenko, A. S.; Gorbunov, A. O.; Panov, M. S.; Tumkin, I. I.; Safonov, S. V. Laser-Induced Copper Deposition from Aqueous and Aqueous-Organic Solutions: State of the Art and Prospects of Research. Russ. Chem. Rev. 2015, 84, 1059-1075.

(2) Eigen, M.; Wilkins, R. G. The Kinetics and Mechanism of Formation of Metal Complexes. Adv. Chem. Ser. 1965, 49, 55-80.

(3) Helm, L.; Merbach, A. E. Inorganic and Bioinorganic Solvent Exchange Mechanisms. Chem. Rev. 2005, 105, 1923-1959.

(4) Helm, L.; Lincoln, S. F.; Zbinden, D.; Merbach, A. E. Solvent Exchange in Hexakis(Methanol) Copper(II) Ion. Oxygen-17 NMR Variable-Temperature, Pressure, and Frequency Study. Inorg. Chem. 1986, 25, 2550-2552.

(5) Pasquarello, A.; Petri, I.; Salmon, P. S.; Parisel, O.; Car, R.; Toth, E.; Powell, D. H.; Fischer, H. E.; Helm, L.; Merbach, A. E. First Solvation Shell of the $\mathrm{Cu}(\mathrm{II})$ Aqua Ion: Evidence for Five-fold Coordination. Science 2001, 291, 856-859.

(6) Prohaska, J. R. Functions of Trace Elements in Brain Metabolism. Physiol. Rev. 1987, 67, 858-901.

(7) Shorrocks, V. Copper in Human Health - A Review; CDA Technical Note 34; Copper Development Association: Potters Bar, Herts, U.K., 1984.

(8) Harris, E D. Copper in Human and Animal Health. In Trace Elements in Health; Rose, J., Ed.; Butterworths: London, 1983; p 44.

(9) Sorenson, J. R. Copper Complexes - A Unique Class of AntiArthritic Drugs J. Prog. Med. Chem. 1978, 15, 211-260.

(10) Barbeau, A. Recent Developments in Parkinson's Disease and Huntington's Chorea. Int. J. Neurol. 1976, 11, 17-27.

(11) Underwood, E J. Copper. In Trace Elements in Humans and Animals, 4th ed.; Academic Press: New York, 1971.

(12) Danks, D. M.; Campbell, P. E.; Stevens, B. J.; Mayne, V.; Cartwright, E. Menkes's Kinky Hair Syndrome. An Inherited Defect in Copper Absorption with Wide-spread Effects. Pediatrics 1972, 50, 188-201.

(13) Danks, D. M.; Stevens, B. J.; Campbell, P. E.; Gillespie, J. M.; Walker-Smith, J.; Blomfield, J.; Turner, B. Menkes' Kinky-Hair Syndrome. Lancet 1972, 299, 1100-1103.

(14) Owen, C. A. Jr. Copper Deficiency and Toxicity, Acquired and Inherited: In Plants, Animals and Men; Noyes Publications: NJ, 1981.

(15) Sternlieb. The Keyser- Fleischer Ring. I. Med. Radiogr. Photogr. 1966, 42, 14-15.

(16) Walshe, J. M. The Treatment of Wilson's Disease with Penicillamine. Lancet 1960, 275, 188-192.

(17) Sykes, A. G. Tilden Lecture. Structure and Electron-Transfer Reactivity of the Blue Copper Protein Plastocyanin. Chem. Soc. Rev. 1985, 14, 283-315.

(18) Dennison, C.; Lawler, A. T. Investigations of the Alkaline and Acid Transitions of Umecyanin, a Stellacyanin from Horseradish Roots. Biochemistry 2001, 40, 3158-3166.

(19) Koch, M.; Velarde, M.; Harrison, M. D.; Echt, S.; Fischer, M.; Messerschmidt, A.; Dennison, C. Crystal Structures of Oxidized and Reduced Stellacyanin from Horseradish Roots. J. Am. Chem. Soc. 2005, 127, 158-166.

(20) Nagasawa, Y.; Fujita, K.; Katayama, T.; Ishibashi, Y.; Miyasaka, H.; Takabe, T.; Nagao, S.; Hirota, S. Coherent Dynamics and Ultrafast Excited State Relaxation of Blue Copper Protein; Plastocyanin. Phys. Chem. Chem. Phys. 2010, 12, 6067-6075.

(21) Cimei, T.; Bizzarri, A. R.; Cerullo, G.; De Silvestri, S.; Cannistraro, S. Excited State Charge-Transfer Dynamics Study of Poplarplastocyanin by Ultrafast Pump-Probe Spectroscopy and Molecular Dynamics Simulation. Biophys. Chem. 2003, 106, 221-231.

(22) Nakashima, S.; Nagasawa, Y.; Seike, K.; Okada, T.; Sato, M.; Kohzuma, T. Coherent Dynamics in Ultrafast Charge-Transfer Reaction of Plastocyanin. Chem. Phys. Lett. 2000, 331, 396-402. 
(23) Edington, D.; Diffey, W. M.; Doria, W. J.; Riter, R. E.; Beck, W. F. Radiationless Decay from the Ligand-to-Metal Charge-Transfer State in the Blue Copper Protein Plastocyanin. Chem. Phys. Lett. 1997, 275, 119-126.

(24) Book, L. D.; Arnett, D. C.; Hu, H. B.; Scherer, N. F. J. Phys. Chem. A 1998, 102, 4350-4359.

(25) Ando, K. Excited State Potentials and Ligand Force Field of a Blue Copper Protein Plastocyanin. J. Phys. Chem. B 2004, 108, 39403946.

(26) Ando, K. Ligand-to-Metal Charge-Transfer Dynamics in a Blue Copper Protein Plastocyanin: A Molecular Dynamics Study. J. Phys. Chem. B 2008, 112, 250-256.

(27) Cimei, T.; Bizzarri, A. R.; Cannistraro, S.; Cerullo, G.; De Silvestri, S. Vibrational Coherence in Azurin With Impulsive Excitation of the LMCT Absorption Band. Chem. Phys. Lett. 2002, 362, 497-503.

(28) Bizzarri, A. R.; Brida, D.; Santini, S.; Cerullo, G.; Cannistraro, S. Ultrafast Pump-Probe Study of the Excited-State Charge-Transfer Dynamics in Blue Copper Rusticyanin. J. Phys. Chem. B 2012, 116, 4192-4198.

(29) Delfino, I.; Manzoni, C.; Sato, K.; Dennison, C.; Cerullo, G.; Cannistraro, S. Ultrafast Pump-Probe Study of Excited-State ChargeTransfer Dynamics in Umecyanin from Horseradish Root. J. Phys. Chem. B 2006, 110, 17252-17259.

(30) Plyusnin, V. F.; Kolomeets, A. V.; Grivin, V. P.; Larionov, S. V.; Lemmetyinen, H. Photochemistry of Dithiocarbamate $\mathrm{Cu}(\mathrm{II})$ Complex in $\mathrm{CCl}_{4}$. J. Phys. Chem. A 2011, 115, 1763-1773.

(31) Mereshchenko, A. S.; Pal, S. K.; Karabaeva, K. E.; El-Khoury, P. Z.; Tarnovsky, A. N. Photochemistry of Monochloro Complexes of Copper(II) in Methanol Probed by Ultrafast Transient Absorption Spectroscopy. J. Phys. Chem. A 2012, 116, 2791-2799.

(32) Glebov, E. M.; Plyusnin, V. F.; Grivin, V. P.; Krupoder, S. A.; Liskovskaya, T. I.; Danilovich, V. S. Photochemistry of Copper(II) Polyfluorocarboxylates and Copper(II) Acetate as Their Hydrocarbon Analogues. J. Photochem. Photobiol., A 2000, 133, 177-183.

(33) da Silva, P. A. C.; David, P. G. Photoredox Chemistry of Copper(II) Perchlorate in Methanolic Medium. Bull. Chem. Soc. Jpn. 1982, 55, 2673-2674.

(34) David, P. G.; da Silva, P. A.C. Photoredox Chemistry of Chloro and Bromo Complexes of Copper(II) in Methanolic Medium. Bull. Chem. Soc. Jpn. 1985, 58, 3566-3569.

(35) Kaczmarek, H.; Kaminska, A.; Linden, L. A.; Rabek, J. F. Photooxidative Degradation of Poly (Ethylene Oxide) - Copper Chloride Complexes. Polymer 1996, 37, 4061-4068.

(36) Cervone, E.; Diomedi Camassei, F.; Giannini, I.; Sykora, J. Photoredox Behaviorof Chlorocopper (II) Complexes in Acetonitrile Mechanism and Quantum Yields. J. Photochem. 1979, 11, 321-332.

(37) Kochi, J. K. Photolyses of Metal Compounds: Cupric Chloride in Organic Media. J. Am. Chem. Soc. 1962, 84, 2121-2127.

(38) Cieśla, P.; Kocot, P.; Mytych, P.; Stasicka, Z. Homogeneous Photocatalysis by Transition Metal Complexes in the Environment. J. Mol. Catal. A: Chem. 2004, 224, 17-33.

(39) Ferraudi, G.; Muralidharan, S. Photochemical Properties of Copper Complexes. Coord. Chem. Rev. 1981, 36, 45-88.

(40) Liu, F.; Cunningham, K. L.; Uphues, W.; Fink, G. W.; Schmolt, J.; Mcmillin, D. R. Luminescence Quenching of Copper(II) Porphyrins with Lewis Bases. Inorg. Chem. 1995, 34, 2015-2018.

(41) Chen, L. X.; Shaw, G. B.; Liu, T.; Jennings, G.; Attenkofer, K. Exciplex Formation of Copper(II) Octaethyl Porphyrin Revealed by Pulsed X-Rays. Chem. Phys. 2004, 299, 215-223.

(42) Kruglik, S. G.; Apanasevich, P. A.; Chirvony, V. S.; Kvach, V. V.; Orlovich, V. A. Resonance Raman, CARS and Picosecond Absorption Spectroscopy of Copper Porphyrins: the Evidence for the Exciplex Formation with Oxygen-Containing Solvent Molecules. J. Phys. Chem. 1995, 99, 2978-2995.

(43) El-Khoury, P. Z.; Kwok, W. M.; Guan, X. G.; Ma, C. S.; Phillips, D. L.; Tarnovsky, A. N. Photochemistry of Iodoform in Methanol Probed by Ultrafast Pump-Probe and Transient Resonance RamanThe Formation and Fate of the Iso- $\mathrm{CHI}_{2}-\mathrm{I}$. Photoproduct. ChemPhysChem 2009, 10, 1895.
(44) Pal, S. K.; Mereshchenko, A. S.; El-Khoury, P. Z.; Tarnovsky, A. N. Femtosecond Photolysis of $\mathrm{CH}_{2} \mathrm{Br}_{2}$ in Acetonitrile: Capturing the Bromomethyl Radical and Bromine-Atom Charge Transfer Complex Through Deep-to-Near UV Probing. Chem. Phys. Lett. 2011, 507, 69.

(45) El-Khoury, P. Z.; Tarnovsky, A. N. Ultrafast Formation of $\mathrm{I}_{2}$ Following 350-nm Photodissociation of $\mathrm{CF}_{2} \mathrm{I}_{2}$ in n-Hexane. Chem. Phys. Lett. 2008, 453, 160.

(46) Voskresenska, V.; Wilson, R. M.; Panov, M.; Tarnovsky, A. N.; Krause, J. A.; Vyas, S.; Winter, A. H.; Hadad, C. M. Photoaffinity Labeling via Nitrenium Ion Chemistry: Protonation of the Nitrene Derived from 4-Amino-3-nitrophenyl Azide to Afford Reactive Nitrenium Ion Pairs. J. Am. Chem. Soc. 2009, 131, 11535.

(47) Pal, S. K.; Mereshchenko, A. S.; Butaeva, E. V.; El-Khoury, P. Z.; Tarnovsky, A. N. Global Sampling of the Photochemical Reaction Paths of Bromoform by Ultrafast Deep-UV Through Near-IR Transient Absorption and ab initio Multiconfigurational Calculations. J. Chem. Phys. 2013, 138, 124501.

(48) Panov, M. S.; Voskresenska, V. D.; Ryazantsev, M. N.; Tarnovsky, A. N.; Wilson, R. M. 5-Azido-2-aminopyridine, a New Nitrene/Nitrenium Ion Photoaffinity Labeling Agent That Exhibits Reversible Intersystem Crossing between Singlet and Triplet Nitrenes. J. Am. Chem. Soc. 2013, 135, 19167.

(49) Nilov, D. I.; Komarov, D. Y.; Panov, M. S.; Karabaeva, K. E.; Mereshchenko, A. S.; Tarnovsky, A. N.; Wilson, R. M. Oxidation of Adenosine and Inosine: The Chemistry of 8-Oxo-7,8-dihydropurines, Purine Iminoquinones, and Purine Quinones as Observed by Ultrafast Spectroscopy. J. Am. Chem. Soc. 2013, 135, 3423.

(50) Reuther, A.; Laubereau, A.; Nikogosyan, D. N. A Simple Method For Thein Situanalysis of Femtosecond UV Pulses in the Pump-Probespectroscopy of Solutions. Opt. Commun. 1997, 141, 180.

(51) Rasmusson, M.; Tarnovsky, A. N.; Åkesson, E.; Sundström, V. On the Use of Two-Photon Absorption for Determination of Femtosecond Pump-Probe Cross-Correlation Functions. Chem. Phys. Lett. 2001, 335, 201.

(52) Ziólek, M.; Lorenc, M.; Naskrecki, R. Determination of the Temporal Response Function in Femtosecond Pump-Probe Systems. Appl. Phys. B: Lasers Opt. 2001, 72, 843.

(53) Hathaway, B. J.; Holah, D. G.; Postlethwaite, J. D. The Preparation and Properties of Some Tetrakis (Mehylcyanide) Copper(I) Complexes. J. Chem. Soc. 1961, 3215-3218.

(54) Helm, L.; Lincoln, S. F.; Merbach, A. E.; Zbinden, D. Solvent Exchange in Hexakis (Methanol) Copper(II) Ion. Oxygen-17 NMR Variable-Temperature, Pressure, and Frequency Study. Inorg. Chem. 1986, 25, 2550-2552.

(55) Persson, I.; Pennerhahn, J. E.; Hodgson, K. O. An Exafs Spectroscopic Study of Solvates of Copper(I) and Copper(Ii) in Acetonitrile, Dimethyl-Sulfoxide, Pyridine, and Tetrahydrothiophene Solutions and a Large-Angle X-Ray-Scattering Study of the Copper(Ii) Acetonitrile Solvate in Solution. Inorg. Chem. 1993, 32, 2497-2501.

(56) Kudrev, A. G. Calculation of the Equilibrium Constants and Cooperative Parameters of Formation of $\mathrm{Cu}$ (II) Chloride Complexes in Nonaqueous Solvents. Talanta 2012, 101, 157-160.

(57) Khan, M. A.; Meullemeestre, J.; Schwing, M. J.; Vierling, F. Detailed Spectrophotometric Study of the Copper(II) Halides in Anhydrous Methanol. Inorg. Chem. 1989, 28, 3306-3309.

(58) Khan, M.; Bouet, G.; Vierling, F.; Meullemeestre, J.; Schwing, M. J. Formation of Cobalt(II), Nickel(II) and Copper(II) Chloro Complexes in Alcohols and the Irving-Williams Order of Stabilities. Transition Met. Chem. 1996, 21, 231-234.

(59) Ishiguro, S.-i.; Jeliazkova, B. G.; Ohtaki, H. Complex Formation and Solvation of $\left(\mathrm{CuCl}_{n}\right)^{(2-n)+}$ in Acetonitrile and in N,Ndimethylformamide. Bull. Chem. Soc. Jpn. 1985, 58, 1749-1754.

(60) Mereshchenko, A. S.; Olshin, P. K.; Karimov, A. M.; Skripkin, M. Y.; Burkov, K. A.; Tveryanovich, Y. S.; Tarnovsky, A. N. Photochemistry of Copper(II) Chlorocomplexes in Acetonitrile: Trapping the Ligand-to-Metal Charge Transfer Excited State Relaxations Pathways. Chem. Phys. Lett. 2014, 615, 105-110.

(61) KTH - Chemistry/Chemical Equilibrium Diagrams http:// www.kth.se/en/che/medusa (accessed December, 21, 2015). 
(62) Kläning, U. K.; Wolff, T. Laser Flash-Photolysis of HClO, ClO-, $\mathrm{HBrO}$, and BrO- in Aqueous-Solution - Reactions of Cl-Atoms and $\mathrm{Br}-$ Atoms. Ber. Bunsen-Ges. Phys. Chem. 1985, 89, 243-245.

(63) Khan, M. A.; Schwing-Weill, M. J. Stability and ElectronicSpectra of Copper(II) Chloro Complexes in Aqueous-Solutions. Inorg. Chem. 1976, 15, 2202-2205.

(64) Chemaly, S. M. Cobalamins and the Spectrochemical Series. Dalton Trans. 2008, 5766-5773.

(65) Lever, A. B. P. Inorganic Electronic Spectroscopy, 2nd ed.; Elsevier: Amsterdam, 1984.

(66) Verkade, J. G.; Piper, T. S. Transition Metal Complexes of a Constrained Phosphite Ester. II. Compounds of Cobalt(I), Cobalt(III), and Nickel(II) with 4- Methyl-2,6,7-trioxa-1phosphabicyclo[2.2.2] octane. Inorg. Chem. 1963, 2, 944-947.

(67) Huheey, J. E. Inorganic Chemistry, 3rd ed.; Harper and Row: New York, 1983.

(68) Beck, W.; Feldl, K. Z. Bindungsverhältnisse in Fulminato-MetallKomplexen. Absorptions- und Reflexions Spektren im sichtbaren und UV-Gebiet. Z. Anorg. Allg. Chem. 1965, 341, 113-123.

(69) Kovalenko, S. A.; Schanz, R.; Hennig, H.; Ernsting, N. P. Ernsting, Cooling Dynamics of an Optically Excited Molecular Probe in Solution From Femtosecond Broadband Transient Absorption Spectroscopy. J. Chem. Phys. 2001, 115, 3256-3273.

(70) Golubeva, E. N.; Zubanova, E. M.; Melnikov, M. Y.; Gostev, F. E.; Shelaev, I. V.; Nadtochenko, V. A. Femtosecond Spectroscopy and TD-DFT Calculations of $\mathrm{CuCl}_{4}{ }^{2-}$ Excited States. Dalton Trans. 2014, 43, 17820-17827.

(71) Plyusnin, V. F.; Bazhin, N. M.; Kiseleva, O. B. The Photochemistry of Copper(II) Chloride Complexes in Solutions in Ethanol. Zh. Fiz. Khim. 1980, 54, 672-675 (in Russian).

(72) Plyusnin, V. F.; Usov, O. M. Chloride Complexes $\mathrm{Cu}(\mathrm{II})$ in Frozen Ethanol Solutions. Zh. Obshch. Khim. 1985, 55, 1455-1459 (in Russian).

(73) Khmelinskii, I. V.; Plyusnin, V. F.; Gritsan, N. P.; Bazhin, N. M. Laser-Pulse Analysis of Frozen Ethanol Solutions of Chloride $\mathrm{Cu}(\mathrm{II})$ Complexes. Khim. Fiz. 1985, 4, 1666-1669 (in Russian). 